\title{
Los regidores municipales de Segovia durante los reinados de Felipe II, Felipe III y Felipe IV
}

\author{
Francisco Javier Mosácula María
}

\begin{abstract}
RESUMEN
ABSTRACT

El enfoque tradicional que se ha dado

a los estudios locales, se ha visto superado por una nueva corriente que trata de conocer la realidad social que

se esconde tras los concejos.

Dejando a un lado la institucionalización del poder local, nuestra principal preocupación ha sido la de intentar desentrañar las

características sociales de los regidores y su vida cotidiana dentro del Ayuntamiento. El mundo urbano en los albores de la Edad Moderna, se caracterizó por la penetración de

una burguesía potente en el entramado social, en un momento de crisis y trasmutación de valores sociales y morales como consecuencia del crecimiento económico, en los que el rico reemplazó al noble, a no ser que éste aceptase las técnicas de enriquecimiento de aquél, en

dirección inversa a las que impulsaron al rico a asumir formas de vida nobiliarias. Este proceso afectó

The traditional focus given to studies of municipal local administrations, has been modified recently by a new tendency which aims to uncover the social reality in which events occurred, details often hidden by the bureaucratic nature of Council documentation. More than just a study of the institutionalization of local administrations, our primary concern is to uncover the social characteristic of the aldermen and their day to day life in the municipal administration. At the onset of the modern age, urban life was characterized by the overwhelming power of the bourgeoisie in the social strata, during a time of crisis and changing of social values and morals, which itself was sparked by a growing economy. In this new stratification, the new wealthy began to replace the nobility in importance, inevitably assuming the characteristics of the noble, which had a detrimental effect on the net
\end{abstract}


de lleno a la oligarquía municipal, que tuvo que renovarse admitiendo en sus filas a los miembros más destacados de esta clase emprendedora, con los que llegó a un pacto y a una interrelación cómplice de intereses, ya que estos últimos no buscaban el triunfo de su clase sino lograr el ascenso social y entrar a formar parte de la sociedad señorial y aristocrática. productive capacity of this new rich. This process met head-on at the administrative level of local governments, which were forced to accept these new rich entrepreneurs among their ranks, in a relationship based on common interests which allowed the new class to ascend in social status forming a part of the aristocracy.

\section{INTRODUCCIÓN}

Algo que ha caracterizado siempre a los estudios locales ha sido su acendrado positivismo. Lo que más preocupaba sobre el ámbito concejil a los historiadores era la institucionalización del poder local. Pero, superada esta etapa, estos estudios comenzaron a desviarse hacía el espacio inmediato del poder, alejándose del ámbito institucional o del marco jurídico tan en boga hasta entonces.

Uno de los objetivos de esta nueva corriente es conocer la realidad social que se escondía tras los concejos, centrando el estudio en el análisis de las oligarquías urbanas y así desentrañar aspectos como el ámbito de su actuación política, la jerarquía interna que se observa en estos grupos y sus niveles de fortuna. Se trata de investigar sobre las características comunes del grupo mediante el estudio colectivo de sus vidas, es decir, se trata de hacer una descripción prosopográfica, en la que lo que más nos interesas son las características externas que presenta cada individuo, para así poder describir al grupo en su conjunto.

El primer historiador español que comenzó a aportar luz sobre el tema y a cambiar el concepto de que la nobleza era algo inerte e inmutable, informándonos sobre el proceso de ingreso, ascenso y transformaciones internas que se producian en estos grupos, fue don Antonio Domínguez Ortiz, en su obra titulada: La sociedad española en el siglo XVII ${ }^{1}$. El influ-

1 Domínguez Ortiz, A., La sociedad española en el siglo xVII. El estamento nobiliario. Madrid, 1963. 
jo de estas nuevas corrientes de estudio provenía de los países anglosajones y centroeuropeos. Lawrence Stone en: La crisis de la aristocracia ${ }^{2}$, llega a la conclusión de que la élite de poder en Inglaterra, queda caracterizada por su tradicional conservadurismo y su convicción de grupo cerrado, en contra de la idea generalizada de que se trataba de un grupo continuamente renovado. Sin embargo, en Francia, los debates historiográficos acerca de la composición de la nobleza de sangre, han terminado por romper los tópicos tradicionales existentes entre la nobleza de sangre y la nobleza de toga, y se ha llegado a la conclusión de que el patriciado urbano, quedaba caracterizado por cambios de origen interno y esto es lo que garantizó su continuidad. Valga como ejemplo de lo que acabamos de decir, la obra de A. Crener titulada: Génesis de la noción de la nobleza de toga ${ }^{3}$.

A partir de entonces, una serie de historiadores españoles como Ana Guerrero Mayllo ${ }^{4}$, Mauro Hernández ${ }^{5}$ y F. J. Aranda Pérez ${ }^{6}$, por citar sólo algunos de ellos, continuaron este tipo de trabajos dedicados al análisis con detenimiento de un cuerpo social definido: Las oligarquias urbanas.

La metodología responde a la necesidad de centrar nuestra investigación en la cuestión social del poder desde el punto de vista sociológico, es decir, la investigación del poder a través del estudio de los grupos de poder. Se trata de trazar una biografía colectiva que abarque, tanto la vida cotidiana de los miembros de estos grupos en su quehacer institucional, como en lo que se refiere a su más estricta intimidad. Así -en este trabajo que presentamos-, la función política y social de los regidores, la calidad de los miembros del grupo, la reproducción social de estas oligarquias; y más adelante -en una segunda parte que complete este trabajo-, sus estrategias familiares, su cultura, su mentalidad, sus bases económicas, etc., darán fin a esta investigación.

STONE, L., An Open Elite? England, 1540-1880. Oxford, 1984.

CREner, A., "La genèse de la notion de noblesse de robe". Revue d" Historie Moderne et Contemporaine, 46-1 (1999), pp. 21/38.

4 Guerrero Mayl.lo, A., Familia y vida cotidiana de una élite de poder. Los regidores madrileños en tiempos de Felipe II. Madrid, 1993. Siglo xx। de España Editores, S. A.; El gobierno municipal de Madrid (1560-1606). Instituto de Estudios Madrileños. Madríd, 1993.

5 Hernandez, M. A la sombra de la Corona. Poder local y oligarquía urbana. (Madrid. 1606-1808). Madrid, 1995.

6 Aranda Pérez, F. J., Poder municipal y oligarquias urbanas en Toledo en el siglo xvill. Ediciones de la Universidad de Castilla-La Mancha, Cuenca, 1999. 
Para conseguir nuestros objetivos, las Actas municipales y todo aquellos documentos, pragmáticas o cualquier otra noticia sobre los regidores, además de los libros de leyes y ordenanzas al respecto, fueron las fuentes fundamentales a las'que recurrimos para cubrir esta primera parte. Y los testamentos, inventarios de bienes, cartas de dote o cualquier otros documento notarial que aporte datos sobre la vida privada de estos individuos, nos ayudarán a completar la segunda parte que dará por terminada esta investigación.

Aunque el método prosopográfico es el dominante en este trabajo no podemos olvidarnos de la historia institucional. El intento de analizar el ejercicio de la autoridad nos lleva al estudio social de la administración a través del estudio particular de cada uno de sus miembros. Se trata de combinar lo político y lo social tras el estudio de la actividad política y la dinámica social de un colectivo determinado.

Tampoco pretendemos prescindir de la necesidad de mostrar una visión panorámica de la ciudad desde el punto de vista geográfico, económico y político-administrativo.

De gran importancia es la necesidad de elaborar una historia social cuantitativa, para llegar a la convicción de que el análisis de la dinámica social y el de la estructura de la población, tienen que ser necesariamente concordantes.

En definitiva no se pretende una descripción del armazón institucional del Ayuntamiento, sino que se pretende tener también presente el ambiente y las circunstancias personales de la vida de estos individuos y el medio en el que se desarrollaron.

\section{LA OLIGARQUIÁA SEGOVIANA. EVOLUCIÓN HISTÓRICA}

Un tema muy debatido siempre ha sido el de la autonomía del poder local y su dependencia del poder central. Para la mayoría de los historiadores románticos el medievo fue un periodo caracterizado por un régimen municipal democrático, y más o menos independiente, frente a un gobierno central débil; por el contrario, la Edad Moderna significó el final de un proceso uniformador de fórmulas de gobierno como consecuencia de la acción centralizadora de la Monarquía.

Pero en la actualidad surgen voces de historiadores cuya máxima preocupación es la revisión de estas ideas y cada vez son más los 
que se preguntan si el dominio fue efectivo y realmente significó la pérdida total de autonomía ciudadana, o si las ciudades accedieron a las exigencias de la Corona, a cambio de una cada vez mayor cota de poder independiente, sobre todo, en el privilegio de administrase a sí mismas.

En lo que sí se suele estar de acuerdo es en que la mayor diferencia entre los dos periodos históricos quizá sea el paso de la diversidad a la uniformidad. También se suele estar de acuerdo en que en la Edad Media el principal campo político era la ejecución de la justicia, que, junto con la administración y el control económico, establecian las bases del gobierno municipal. Cabe preguntarse: ¿No sería éste el principal pretexto para la intervención de lo estatal en el ámbito local? De ser así, ¿no se pondría en entredicho la casi mítica e idealizada autonomía democrática concejil de los tiempos de la Repoblación?

En el año 1076, el Rey Alfonso VI, donó al monasterio de Santo Domingo de Silos el lugar de San Frutos. A la señalización del territorio asistieron, por mandato del Rey, los 26 primeros pobladores de Sepúlveda en calidad de testigos de dicha donación. En ningún momento el Rey se refiere al Concejo sino a los 26 primeros pobladores, algo que puede interpretarse no como los primeros pobladores en el tiempo, sino como los más notables y destacados de la villa. En el año 1086 se menciona a un merino del Rey como encargado de dirigir la acción repobladora, lo cual quiere decir que aun no existía un concejo que dirigiera dichas tareas ?

Sabemos que Alfonso VI dotó a los concejos de la Extremadura Castellana de un derecho privilegiado de frontera. En el Fuero de Sepúlveda ${ }^{8}$ se describe a las autoridades de la villa divididas en dos grupos: los representantes del poder superior, como el merino o el alcalde de castillo; y el juez, que debia ser vecino de la villa y de elección anual, lo que significaría un principio de autonomía municipal.

La peligrosidad del poblamiento de frontera colocaría en un lugar preeminente a los hombres encargados de su defensa y dejaría en sus manos las decisiones concejiles. A partir del año 1130, el Rey comen-

Sáez, E., Colección Diplomática de Sepúlveda. Segovia, 1956, pp 3/11.

Sáez, Gillbert, Alvar y G. Ruiz-Zorrilla, Los fueros de Sepúlveda. Segovia, 1953. Publicaciones Históricas de la Excma. Diputación Provincial de Segovia. Dirigida por Pascual Marín Pérez. Serie 1. ${ }^{a}$. Colección de Documentos para la Historia de Segovia. 
zó a recompensar a estos caballeros con privilegios individúales y concejiles como premio a su colaboración en las campañas llevadas a cabo en el sur peninsular ${ }^{9}$. De este modo, el gobierno de las villas fue pasando de forma progresiva del delegado regio al Concejo. Los más antiguos privilegios concedidos a Segovia que se conocen van dirigidos al Concejo de la ciudad o a los varones segovianos. Diego de Colmenares incluye en su Historia de Segovia, entre otros, un privilegio fechado en 25 de mayo de 1190 , otro en 28 de julio de 1208 y un tercero del 12 de diciembre del mismo año. El primero va dirigido al Concejo de Segovia, el de julio de 1208 a "vos los varones de Segovia» y el tercero vuelve a ir dirigido al Concejo de Segovia. Este apelativo de "varones" nos muestra que el gobierno de la ciudad no estaba en manos de los miembros del estado llano sino más bien en poder de los vecinos más significados de la ciudad.

Durante el reinado de Fernando III se produjo un ordenamiento regio destinado a unificar jurídicamente a todos los concejos. En el año 1222, el monarca facultó a los concejos para la elección de todos sus aportellados et adelantados según su propio fuero, pero con la obligación de comunicarlo al Rey para su aprobación ${ }^{10}$. De esta forma se inició una política regia intervensionista en los nombramientos concejiles. Este objetivo de unificación jurídica fue proseguido por Alfonso $X$ con el otorgamiento del Fuero Real de 1256 para la Extremadura Castellana. La recepción del fuero no encontró resistencia, salvo en lo relativo al nombramiento de oficiales concejiles y a la recaudación de impuestos por parte del monarca, y así se inició el proceso de pérdida de autonomía de los concejos extremaduranos.

Según estos datos, si alguna vez existió una verdadera autonomía concejil fue entre el momento en que desaparece la figura del delgado regio al frente del gobierno, sustituido por los Concejos de Villa y Tierra, y el reinado de Fernando III en el que su ordenamiento obligó a las ciudades a presentar listas de los oficiales para su posterior aprobación por el Rey. Y en cuanto a la democracia del sistema, la concesión de privilegios concejiles a un determinado grupo de pobladores, pone en entredicho tal denominación.

9 Colmenares, Diego de, Historia de Segovia, Segovia, 1969, I, cap. XIII pp. $217 / 219$ y cap. XIV, pp. $227 / 232$.

10 González y González, J., Reinado y diplomas de Fernando III. Tomo II. Documentos (1217-1232). Córdoba, 1983, documentos núms. 166, 169 y 809. 
La población medieval en los años que siguieron a la actividad repobladora fue eminentemente rural. Las primeras ciudades surgieron como emanación del mundo rural próximo ligadas a él por razones de tipo económico, jurídico y social. En la ciudad se reprodujo el modelo de estructura jerarquizada, donde la organización del poder reflejaba la estratificación de nobles, laicos y eclesiásticos, en primer lugar; campesinos, en el nivel inferior; $y$, en una posición intermedia, la diversificación que suponía el mundo artesanal y del comercio. Estos "ciudadanos" o "burgueses» fueron los protagonistas de la movilidad social, como consecuencia de la acumulación de riquezas, y ejercieron cierta rivalidad sobre las clases sociales dominantes.

La defensa del territorio quedó en manos de los que podían mantener caballo y armas, es decir, los caballeros villanos, y el gobierno de la ciudad fue su competencia más inmediata. Fundamentalmente basaban su riqueza en la posesión de la tierra y en la práctica de la ganadería. Estaban exentos de pechos y era sobre estos bienes sobre los que estaban escusados por los privilegios alfonsíes.

Estos grupos que dominaban el Concejo en los años que siguieron a la Repoblación, al quedar liberados de las cargas militares directas como consecuencia del alejamiento de las fronteras, pudieron incrementar sus actividades económicas y fomentar las actividades artesanales y mercantiles, lo que hizo posible que las diferencias sociales y políticas entre los caballeros urbanos y el resto de la población fueran cada vez más importantes. Es probable que a lo largo del siglo XIII algunos caballeros dominasen la ciudad aprovechando su preeminencia social y económica, y a través de lazos de sangre y fidelidad personal, dieran lugar a la formación de linajes dentro de esta oligarquía urbana en lucha constante por el dominio del gobierno de la ciudad.

En las Ordenanzas de 1256 se colocaba en situación de inferioridad a los caballeros que mantuviesen un oficio al mismo tiempo que caballo y armas "1. Como consecuencia de esta situación la división de las élites se fue haciendo tan grande que, al filo de 1300, era verdaderamente imposible ejercer el gobierno de la ciudad ${ }^{12}$. La única solución

11 Archivo Municipal de Segovia (A.M.S.), Ordenanzas estatuidas por el Rey Alfonso $X$ para el Concejo de la Ciudad y Tierra de Segovia, el día 22 de septiembre de 1256. Orig. núm. 10. Copia en el Becerro, fols. 19 y 20.

12 Colmenares, Diego de, op. cit., tomo I, cap.XXIII, 11, pp. 439 y ss. 
consistía en pacificar a los diferentes bandos enfrentados estableciendo un sistema razonable de reparto de poder entre ellos. En las Cortes de Medina del Campo de 1302 se propuso el reparto de poder municipal entre los linajes locales y la vida política de Segovia pudo entrar en un periodo de tranquilidad.

En 1345 se estableció en Segovia el Concejo cerrado o Regimiento y se repartieron los oficios entre los miembros de los linajes existentes en ella. El Regimiento quedó formado por cinco caballeros del linaje de Día Sanz, otros cinco del linaje de Fernán García, dos hombres buenos pecheros de la Ciudad y tres representantes de la Tierra ${ }^{13}$. De este modo quedó cristalizada una realidad social, que desde hacía años venía existiendo y que constituía la garantía de su gobierno. El dominio del Ayuntamiento quedaba en manos de la oligarquía militar de los caballeros, pero los vecinos pecheros de la Ciudad y los habitantes de la Tierra, también encontraban un lugar en le Concejo urbano donde poder hacer oír su voz.

La intervención regia al establecer el Regimiento introdujo en el sistema de poder local un nuevo elemento: los nuevos regidores ya no lo eran por decisión o acuerdo entre los linajes segovianos, sino que eran nombrados por el Rey aunque salieran del estamento caballeresco. Esta situación dio lugar a que se fuera formando poco a poco una reducida élite de caballeros que anteponía sus propios intereses a los del grupo del que procedían. Lo mismo podríamos decir sobre los regidores nombrados entre los pecheros, tanto de los de la Ciudad como de los de la Tierra. Precisamente, el Ordenamiento de la Ciudad y Tierra formado el día 5 de octubre de 1371 se llevó a cabo, entre otras razones, porque tanto los caballeros no regidores como los pecheros, estaban siendo separados de su participación en la vida del Concejo por los regidores ${ }^{14}$.

Pero a pesar de este ordenamiento las diferencias continuaron entre la aristocracia Segovia, es decir, entre los caballeros regidores y los caballeros no regidores agrupados en los Nobles Linajes. Para intenta limar estas diferencias fue por lo que se produjo la Sentencia Arbitral

13 A M S, Carta del Rey Alfonso XI constituyendo el Regimiento de Segovia, el día 5 de mayo de 1345. Pergaminos, cap. VII, doc. 3 . Inserto en la confirmación de Juan I de 3 de noviembre de 1379 .

14 Ibidem, Ordenanzas del Común y Nobles Linajes de la Ciudad y Tierra de Segovia. Doc. $n .{ }^{\circ} 27$. inserto en la confirmación de D. Juan II de 20 de marzo de 1420. 
de 1433. En este acuerdo no participaron ya los pecheros y se repartieron los oficios municipales entre los dos grupos de caballeros ${ }^{15}$.

Durante el reinado de Enrique IV el número de regidores subió a dieciséis: 6 de los caballeros, 6 de los ciudadanos y 4 de los Nobles Linajes, lo que viene a demostrar la pérdida de influencia de esta institución en el gobierno de la ciudad. Precisamente es a partir de este momento cuando comienzan a ingresar en el Regimiento individuos precedentes del mundo de las finanzas, e incluso de origen converso, que en el siglo siguiente estarán perfectamente integrados entre los miembros de la caballería tradicional segoviana.

Años después, durante el reinado de los Reyes Católicos, el número de regidores aumentó a veinticuatro: 16 de los caballeros, 6 de la Tierra y 2 del Común de la Ciudad ${ }^{16}$ y desde el año 1494 todos los regidores gozaron de las preeminencias propias del oficio desde un plano de igualdad, acabando con las diferencias existentes entre ellos como consecuencia del estamento de origen del que procedieran.

Si en un principio los regidores del Común eran los que más cerca estaban de los pecheros. Esta situación cambió en el transcurso del siglo XV, sobre todo en los años finales de siglo, al empezarse a nombrar entre los miembros de la aristocracia urbana, y de esta forma perdieron toda conexión con el Común. En 1497 se llegó a un acuerdo entre los regidores y la Comunidad en el que tras perder el Común la representatividad de sus regidores, se pidió que los procuradores del Común estuviesen presentes en las reuniones del Concejo en las que se tratase asuntos concernientes al Común, con voz pero sin voto. Esto mismo ocurrió con los representantes de la Tierra. De este modo la Comunidad se vio liberada de la tutela de los regidores del Común y de los de la Tierra, por quienes no se sentían representados.

La desvinculación total con sus grupos de procedencia no impidió que los regidores siguiesen abusando de su poder y usurparan los ofi-

15 Ibidem, Sentencia Arbitral entre los caballeros regidores y los caballeros no regidores, sobre los oficios de república. Nobles Linajes, caja 9 , doc. 9.

16 Archivo General de Simancas (A G S) / Consejo Real, Leg. $70-4$, fois. 23 y 24 . Salamanca, 6 de marzo de 1505. «ltem se cree que del dicho tiempo inmemorial en el regimiento de la dicha cibdad a avido dos estados de regidores, el uno estado es de los caballeros en que a avido diez y seys regidores e el otro estado de los buenos ombres pecheros, de los quales a avido ocho regidores..." 
cios que correspondía ejercer a los caballeros no regidores y a los hombres buenos pecheros.

Si hasta entonces los grandes nobles habian ejercido gran influencia en los concejos, formando parte de los regidores o a través de personas de su confianza, los Reyes Católicos acabaron con este estado de cosas. Al ser los regimientos de nombramiento real y aumentar el número de miembros del Regimiento, poco a poco fueron poniendo en el Concejo segoviano personas de su absoluta confianza y dispuestos a defender sus intereses, acabando así con el predominio que hasta entonces habían tenido los grandes nobles como cabezas de las diferentes banderías existentes en el Reino.

Normalmente el modo de proveer los regimientos se hacía a petición y propuesta del Concejo y casi siempre se atendía el principio hereditario tras la súplica del anterior miembro ${ }^{17}$. Algo que el Rey solía confirmar sin el más mínimo problema. Este sistema permitía la acumulación de regimientos en poder de la alta nobleza. Quizá por aso, años después, Felipe II concedió a los regidores la facultad de renunciar sus oficios en la persona en quien quisieran. De esta forma se puso a salvo de las maniobras de los nobles, pero puso definitivamente el poder municipal en manos de la oligarquía urbana ${ }^{18}$. Es posible que se pretendiera crear una oligarquía urbana fuerte que no dependiera de otros poderes instalados en el marco de la ciudad y que pudiese ser apoyo firme de la Monarquía en los periodos de enfrentamiento con la nobleza.

Después de este breve resumen histórico ya podemos establecer como primera conclusión que el Municipio estaba en manos de una oligarquía dotada de un considerable poder y que merced al mecanismo de las renuncias ya se empezaba a enraizar en sus cargos. Los concejos habían comenzado a cerrase en oligarquías que se reproducían por sí mismas, sobre todo, a partir de la segunda mitad del siglo $\mathrm{xV}$. También hemos visto la composición social de esta oligarquía y su evolución a través del tiempo. O sea que, podemos afirmar que se trataba de ayuntamientos oligárquicos en los que nada quedaba de aquellos principios democráticos de las asambleas generales de vecinos de los momentos de la Repoblación. en 1436 .

NOVISIMA RECOPILACIÓN, Libro VII, título VIII, Ley II. Don Juan II en Guadarrama

18 A.G.S. / Registro General del Sello, VIII, Tudela de Duero, 17 de agosto de 1506. 


\section{SEGOVIA. LA CIUDAD Y SU AMBIENTE. EL GOBIERNO MUNICIPAL}

\section{La ciudad y su ambiente}

A comienzos del siglo xvı la ciudad, con intensa conciencia de sí misma, poseía una fuerza política propia y no había quedado reducida aún a una mera entidad administrativa. Un claro ejemplo es, sin duda alguna, el levantamiento comunero.

Este mundo urbano corresponde a los albores de la modernidad y se caracteriza por la penetración de una burguesía potente en el entramado social, encabezado por una estamento nobiliario tradicional y en un marco de relaciones, valores y comportamientos sociales establecidos que afectaban a toda la sociedad. El poder de esta burguesía residía en su riqueza y su peso era típicamente urbano, y, no cabe duda, que sus intereses eran contrapuestos, aunque muchas veces se complementaran con los de la sociedad señorial y aristocrática tradicional. Existía una crisis y una trasmutación de valores sociales y morales, que se desarrolló en la fase de crecimiento económico y cultural de la sociedad de entresiglos. El rico reemplazó al noble de rancio linaje, a no ser que éste aceptara las técnicas de enriquecimiento de aquél, en dirección inversa a las que impulsaron al rico a asumir formas de vida nobiliarias ${ }^{19}$.

EJ ambiente industrial del siglo XVı contagió a la ciudad y sólo en el XVII volverán a revalorizarse las formas y modelos señoriales. Había dinero, trabajo, posibilidades, el índice de movilidad social creció considerablemente. El poder de la riqueza, el individualismo, la desvinculación del asalariado, las relaciones económicas, la adquisición no heredada de honores, la caracterización frente a los esquemas nobiliarios, la expansión urbana, era todo los que caracterizaba el mundo de las relaciones sociales de la época.

Es conocida la llegada de nuevas familias a Segovia que se afincaron y prosperaron en ella o la ascensión social de los conversos que llegaron a obtener el grado de nobleza, desde el reinado de Enrique VI

19 Maraval, J. A., El mundo social de la Celestina. Madrid, Gredos, 1964, p. 18. 
hasta los años Treinta de la centuria siguiente. El mundo de los caballeros se ensanchó como consecuencia de ello en una nueva clase patricia de grandes señores.

Los protocolos notariales entre el año 1500 y 1580 nos muestran que el obraje de los paños era el negocio de los comerciantes segovianos. Hasta 1540 los contratos relacionados con el textil suponían el $40 \%$ de las actas notariales, después de esta fecha y hasta 1580 , esta relación subió al $80 \%$. Esto quiere decir que los que se enriquecían en Segovia eran los que se dedicaban a estas actividades. Y los que de entre ellos no reparaban en gastos, ponían todo su empeño en conseguir la condición de hidalgos y por ser admitidos en la institución nobiliaria de los Nobles Linajes. Este reconocimiento social les abría las puertas del Ayuntamiento y, primero los mercaderes y después los fabricantes de paños, a través de la compra de oficios se fueron haciendo un hueco entre los regidores municipales.

La reacción no se hizo esperar. Por parte de las fuerzas tradicionales de la ciudad se empezaron verter acusaciones contra los mercaderes de hacer unos negocios fabulosos y se empezó a colocar al margen de la sociedad a los sectores más dinámicos e industriosos. El siglo XVII trajo consigo el hundimiento de los fabricantes de paños y el triunfo de los ganaderos. La razón no fue otra que el principio de rentabilidad. En primer lugar la rentabilidad económica: la exportación de lana reportaba más beneficios que la fabricación de paños; en segundo lugar la rentabilidad social: el éxito en el sector textil no garantizaba la admisión en los Nobles Linajes segovianos..

La Segovia del Quinientos: del paño, de la lana, fabril, urbana, burguesa; la Segovia del Seiscientos: de la lana, ganadera, rural, señorial. Contraste de formas de vida burguesa a formas de vida caballeresca, del ideal industrial al ideal ganadero ${ }^{20}$. Crisis económica y mutación social. A partir de 1610 el mundo textil se empieza a esfumar de entre la clientela de los escribanos. En 1580 significaba el $80 \%$ de los contratos, en 1630 habían quedado reducidos al 5\%. Dos tipos de contratos los reemplazaron: el cobro de juros y el registro de balas de lana exportadas.

\footnotetext{
20 LE FLEM, J.P., “Vraies et fausses splendeurs de l' industrie textile segovienne " (vers 1460-vers 1650). Instituto Internazionale di Storia Económica F. Santini, Prato, Firenze, 1976 , pp. 528:533.
} 
Segovia era, sobre todo, una ciudad de trabajadores. De los 4487 vecinos que se contabilizaron en el censo de 1561, 3301 eran activos, esto es, el $73,56 \%$ del total. A la actividad industrial se dedicaban 2529 de estos vecinos, es decir, el 76,6\% de los activos; sin embargo, los sectores primario y terciario sólo acogian a 672 vecinos, 10 que suponía el $20,3 \%$ de la población activa. En 1570 se pueden mencionar más de cincuenta clases de industrias diferentes. La enumeración y la disposición de los grupos en el desfile de bienvenida que se celebró con motivo de la boda de Felipe II con Ana de Austria, no sólo nos muestra la diversidad ocupacional que ofrecía Segovia sino también el ordenamiento jerárquico de la vida urbana basado en el trabajo ${ }^{21}$.

La decadencia de 1598 no fue tan brusca como siempre se ha creído. Múltiples testimonios avalan la falta de conciencia de crisis en la Segovia de las primeros décadas del Seiscientos. La novela de Jerónimo Alcalá Yánez, El donado hablador, todavía cuenta que la Segovia de 1625 era una ciudad de "caudaloso trato", ciudad rica y de "hacedores de paños sin número" ${ }^{22}$. En estas fechas la producción sólo habia caído un $30 \%$ en relación con la época de máximo esplendor.

En el siglo XVII Segovia sufrió un proceso de ruralización en el que no hay que confundir su ruina industrial y su postración social, con el cese de la prosperidad de sus grupos dirigentes amos de campos y ganados. La reacción señorial que se produjo acompañada de mayores exigencias fiscales, disminución de la producción y crisis comercial, se agravó por la tendencia de la burguesía a desertar de sus tratos habituales en busca de ennoblecimiento.

La evolución de la población, su distribución por la ciudad, los sectores de actividad, la localización urbana de los grandes grupos sociales, la existencia de minorias, etc., son aspectos básicos para reconocer su cuerpo social. Población y economía están intimamente unidas y es la industria textil la que aporta mayor número de datos indicativos. No obstante, la falta de inversiones en actividades productivas y la preferencia por inversiones en bienes raíces primero, y de censos y juros después, fueron determinantes para provocar una doble crisis coyun-

\footnotetext{
21 LeCEA y García, C. de, Recuerdos de la antigua industria segoviana. Segovia, 1897, F. Santiuste, pp. $20 / 21$

22 ALCALÁ Yánez, J., El donado hablador, Alonso mozo de muchos amos. BAE., XVIII, Madrid, 1946, p. 575.
} 
tural de la economía y de la población. A estos hechos se unieron la carestía generalizada producida por la llegada de los tesoros americanos, la reducción de los precios de las materias primas, y, por último, la sucesión de pestes y calamidades públicas que se repitieron a partir del año 1599 y durante las primeras décadas del siglo XVII. Siendo particularmente graves la sucesión de pestes y hambrunas que ocurrieron desde 1626 a 1632 . Pero lo más grave no fueron las bajas que se produjeron como consecuencia de las enfermedades y el hambre, sino la emigración que de forma sincronizada a las oleadas de hambre y muerte se produjo como consecuencia de ellas ${ }^{23}$.

En 1531 había en Segovia 2850 vecinos pecheros ${ }^{24}$, si en 1561 el padrón declara que existían en Segovia 4487 vecinos ${ }^{25}$, significa que se produjo un aumento aproximado de 1500 vecinos en un periodo de 30 años. Pero uno de los mornentos de mayor auge demográfico fue el comprendido entre 1579 y 1591 , años en los que el número de vecinos llegó a alcanzar la cifra de 5294, de los cuales 3926 eran pecheros, 529 hidalgos y 739 pertenecientes al clero ${ }^{26}$.

No es fácil cuantificar a los vecinos partiendo de los datos que nos ofrecen los vecindarios, pues depende del coeficiente que utilicemos y de los criterios de que nos sirvamos a la hora de contabilizar a las personas reflejadas en ellos. Por diversas razones hemos creído conveniente utilizar el coeficiente 3,75 al considerar que se acerca más a la realidad demográfica de la época. Si aplicamos dicho coeficiente a los 4487 vecinos del vecindario de 1561 y a los 5294 vecinos del vecindario de 1586 nos salen 16.826 y 19852 habitantes respectivamente ${ }^{27}$.

El recinto amurallado de Segovia estaba habitado por el grupo minoritario de la reducida nobleza local. Éste era el grupo con reconocimiento social y económico que comprendía también al naciente grupo de la burguesía económica, profesional y del comercio; entre ellos hay que incluir también a la clerecía. En el resto de la ciudad la más amplia clase de los trabajadores, las minorías étnicas y religiosas y los grupos

23 A.M.S., Libro de Actas n. ${ }^{\circ}$ 1033, sesión del 12 de febrero de 1631.

24 A.G.S., Sección Contadurias Generales, Leg. 768.

25 Ibidem, Sección Expedientes de Hacienda, Leg. 165-5.

25 Ibidem, Leg. 165-6.

27 En lo que respecta al coeficiente a utilizar a la hora de calcular el número de vecinos seguimos el criterio utilizado por el profesor Angel GARcia SANZ, en su obra, Desarrollo y crisis del antiguo Régimen en Castilla la Vieja. AKAL, Madrid, 1986, p. 43. 
marginales. En definitiva, una población plural y diversa de la que dan fe los vecindarios.

El grupo de la burguesía era minoritario aunque en continua expansión. Al ensancharse la actividad económica, la oligarquía minoritaria en el poder perdió posiciones que la obligaron a un pacto y entendimiento con el nuevo colectivo ascendente y a una interrelación cómplice de intereses. A lo largo del siglo xvi se produjeron aigunos cambios de interés en las relaciones de los grupos de la burguesía económica, de los funcionarios, de las profesiones liberales, y de la pequeña nobleza local. Se trataba de una ampliación de las vinculaciones interfamiliares en las que el poder económico y el poder municipal se intercambiaban.

De los 4487 vecinos de 1561 se repartían el $31,95 \%$ en el centro urbano y el $68,05 \%$ restante en el arrabal. La gran masa de mano de obra de localizaba en las parroquias arrabaleras, donde se localizaban 2365 vecinos activos frente a los 936 del recinto amurallado. Según este censo, todos los regidores de Segovia, excepto uno, vivían en el recinto amurallado. Los censos de 1586 y 1611 no cambian las cosas sustancialmente. Quizá lo que más llame la atención es el hecho de que en 1561 habia un 13,2\% de pobres y en 1586 este porcentaje habia aumentado hasta el $38,9 \%$, lo cual quiere decir que la pauperización había crecido por encima de la demografía.

\section{El gobierno de la ciudad}

El gobierno de la Comunidad correspondía a dos órganos distintos y teóricamente equipotentes que coexistían en la misma función: el Corregidor y el Ayuntamiento, o lo que es lo mismo, la justicia y regidores.

El Ayuntamiento estaba formado por la asamblea de veinticuatro regidores, procedentes de la aristocracia local, a los que se incorporaban dos procuradores del Común y otros dos procuradores de la Tierra y, en El Libro Verde, reivindica su propia titularidad de la administración municipal ${ }^{28}$.

28 A.M.S., El Libro Verde. Cuaderno comprensivo de la organización, usos y costumbres jurídicas del municipio y que escribió el regidor segoviano don Francisco Arias de Verástegui en el año 1611 por encargo del Ayuntamiento de la ciudad. 
Todos los acuerdos se debían tomar en el Consistorio, cuyas sesiones eran presididas por el Corregidor, flanqueado a derecha e izquierda por los regidores más antiguos de cada banco. Los únicos que tenian voz y voto en el Ayuntamiento eran los regidores. El Corregidor no tenía voto salvo en los supuestos de igualdad y en este caso su voto hacia mayoría.

El Ayuntamiento poseía una especia de capacidad de sucesión provisoria del Corregidor para que, en caso de muerte del mismo o por privación de su oficio, el Ayuntamiento pudiera elegir al que hubiere de sucederle en el entretanto en que el Rey nombraba a quien debía de sustituirle.

En Segovia había dos escribanos que, junto con la justicia y regidores, formaban parte del Ayuntamiento, teniendo que asistir a sus reuniones para dar fe de todo lo actuado, pero sin voz ni voto.

El Corregidor presidía las sesiones. Pero al tratarse de poderes adjuntos y, en cierta medida equivalentes, quien presidía el Ayuntamiento era su decano, es decir, el regidor más antiguo, quien poseía el primer asiento y primer voto además del derecho de representar a la ciudad en los actos públicos.

La Corporación de los veinticuatro regidores constituía el Ayuntamiento propiamente dicho y asumía la representación de la ciudad. Es evidente su significación minoritaria y oligárquica, y el hecho de que los estamentos populares no fueran participes del gobierno de la Comunidad, excepto en cuanto a la intervención que se les permitía por la vía, limitada y no decisoria, de los procuradores del Común y de la Tierra, así lo prueba. Los procuradores del Común y los procuradores de la Tierra, de elección popular, constituian el único elemento democrático que se integraba en la estructura política de la Comunidad de la Ciudad y Tierra de Segovia.

El Ayuntamiento representaba a todo el pueblo y como tal tenía su potestad. El ceremonial de sus reuniones estaba perfectamente protocolizado y no dejaba lugar a la improvisación. Lo mismo podríamos decir de las apariciones en público, bien para el recibimiento de reyes o en las honras y exequias que se celebraban en ocasión de su fallecimiento, o bien para asistir corporativamente a las procesiones y actos públicos que así tenían estipulado por costumbre.

El Ayuntamiento, además, tenía la potestad de poder nombrar a los oficiales necesarios para cubrir los distintos oficios municipales. Elegía 
a dos procuradores en Cortes y los demás oficios de república como eran los letrados de ciudad, los procuradores en ella y en los Concejos y Chancillerías, médicos, cirujanos, cambios, mayordomos, receptores, tesoreros, depositario general, preceptores de gramática y de escuela, guardas, veedores y examinadores de los oficios, porteros y demás ministros para la ejecución de la justicia.

\section{CALIDAD DEL OFICIO DE REGIDOR. FORMALIDADES Y REQUISITOS}

Los regidores eran los que verdaderamente sustentaban el gobierno de la ciudad. Se dividían en dos bancos por mitad: el de Día Sanz y el de Fernán García —en recuerdo de los "míticos" capitanes fundadores de los Nobles Linajes, institución de la que en estos tiempos estaban totalmente desvinculados- y a principios de año los regidores se cambiaban de banco como prueba del carácter honorífico de tal denominación. La distinción de los bancos no era de estamentos sino de linajes, por lo que los regidores que representaban a los ciudadanos siempre estuvieron adscritos a uno u otro banco, pero mezclados entre los caballeros.

Los regidores ciudadanos eran adinerados hombres buenos, cuyas riquezas procedían del ejercicio de las actividades mercantiles y manufactureras, que pretendían ascender al escalafón noble-caballeresco, es decir, que ocupaban en la sociedad un término medio entre los hidalgos y los pecheros al vivir de su hacienda y no de oficios mecánicos. También se encontraban en este grupo social todo el conjunto de profesionales liberales que tenían su asiento en la ciudad.

\section{a) Calidad del oficio de regidor}

El oficio de regidor era un oficio público lo que significaba tener gran dignidad y honra. Hasta tal punto llegaba su calidad que representaban al pueblo y eran la ciudad misma ${ }^{29}$. Tenían una serie de privilegios ante la ley que les ponía por encima de los demás ciudadanos:

29 Ibidem, cap. II. 
no podían ser sometidos a tormento ni condenados a ciertas penas como las de azotes y a galeras y tampoco se les podía condenar a muerte sin consultar con el príncipe. En un principio estuvieron exentos de pagar pechos y servicios reales, aunque en la época que nos ocupa no se cumplía, pero de lo que sí estaban exentos era de todo tipo de carga personal.

El hecho de ser regidor proporcionaba a estos señores una serie de privilegios a la hora de adquirir bienes y servicios cotidianos, a la vez que se les permitía llevar armas en horas y en lugares prohibidos, ya que, debido a su jurisdicción, en caso de flagrante delito podían prender al delincuente, desarmarle y encarcelarle.

El ejercicio del cargo estaba exento de responsabilidad, por lo que no estaban obligados a responder con sus personas y haciendas por las deudas contraídas por el Concejo, ya que el oficio de regidor no podía ocasionarlos perjuicio alguno. Aun habiendo dejado el oficio de regidor, les continuaba en vigor dicho privilegio. No obstante, también tenían ciertas limitaciones. Por ejemplo: no podían donar tierras concejiles, salvo huertas, corrales y solares para los vecinos; tampoco podían vender ni enajenar los bienes raíces de la ciudad; también tenían prohibido arrendar las dehesas sin información de su utilidad. Lo que sí podían hacer, con licencia real, era vender algunos bienes de la ciudad, siempre y cuando no fueran comunes ni de uso público, como por ejemplo los dejados en mandas testamentarias. Aunque tenían limitado su campo de acción, por su calidad de administradores de estos bienes, tenían posibilidades de practicar toda clase de corruptelas en su propio beneficio.

En lo que sí estaban verdaderamente limitados por parte del Concejo, era en no excederse de los poderes e instrucciones que se les daban cuando iban en representación de la ciudad en las convocatorias de Cortes.

El Concejo no tenía jurisdicción para imponer la pena de muerte ni cualquier otra pena corporal, ya que no tenía mero y mixto imperio. Los regidores solamente tenían poder para el gobierno de la hacienda pública y para tratar de sus encabezamientos y de otras cosas limitadas, pero no de pleitos entre partes que dependían de la Justicia. En el orden de jurisdicción, el Ayuntamiento tenía competencia en las causas de recusación y en las de apelación. Los regidores también tenían jurisdicción para hacer ordenanzas, pero para este caso se requería la 
presencia del Corregidor, pues para ello era absolutamente necesaria la confirmación por parte de la Justicia ${ }^{30}$.

\section{b) Formalidades y requisitos}

El título de regidor era otorgado por el Rey generalmente como prueba de agradecimiento por los servicios prestados por el antecesor en el cargo y los que esperaba recibir por parte del aspirante. Con dicho título, expedido por el Consejo de la Cámara, se dirigían al Ayuntamiento para requerir su obediencia y cumplimiento y para ser admitido al uso y ejercicio del cargo. Previamente a la concesión del título, el anterior titular había renunciado su oficio en manos de S. M. y a favor del aspirante, algo que el monarca solía conceder sin mayor problema, pero con la condición de que el renunciante hubiese vivido los 20 días que ordenaba la ley después de la fecha de la renuncia y de que el interesado se presentase en el Ayuntamiento antes de transcurridos 60 días contados también a partir de la fecha de la renuncia.

Cumplidos los trámites de presentación del título, renuncia y fe de vida, se procedía al recibimiento con el ceremonial acostumbrado. Superadas estas formalidades, se mandaba entrar el futuro regidor con el fin de proceder a la toma del juramento preceptivo, y, una vez efectuado éste, la última formalidad era la admisión al uso y ejercicio del oficio. Como prueba de posesión se le otorgaba el asiento y lugar en uno de los bancos del Concejo, hecho que simbolizaba exteriormente la investidura ${ }^{31}$.

Los requisitos necesarios que había de reunir para ser regidor eran: ser natural del reino y vecino de la ciudad, ser hábil y suficiente, acreditar nobleza y limpieza de sangre y ser mayor de 18 años de edad. No podían acceder los que practicasen oficios mecánicos, los escribanos, ni los mercaderes, sino que los más a propósito para el oficio, según la opinión de Castillo de Bobadilla, eran los hijos de los propios regidores ${ }^{32}$. No

30 Castillo de Bobadilla, Jerónimo de, Política para corregidores y señores de vasallos. Edición facsímil publicada en Madrid por la Imprenta Real de la gaceta, 1775. Biblioteca provincial de Segovia, 2 volúmenes, sigs, 70.438 y 70.439 . Libro III, caps. VII y VIII.

31 Novísima Recopilación, Libro VII, título VII. A.M.S., El Libro Verde, cap, II. Y Libro de Actas n. ${ }^{\circ}$ 1003, sesión del 28-3-1572 y Libro de Actas n. ${ }^{\circ} 1004$, sesión del 8-6-1576

32 Castillo de Bobadilla, Jerónimo de, op. cit., Libro III, cap. VIII, 8. 
cabe duda que esta era una de las razones que explican la endogamia existente en el Ayuntamiento y entre los miembros de este colectivo en particular.

Esta era la letra de la Ley, pero la realidad era muy distinta, pues, como el título era una merced real, era el propio Rey quien rompía la norma y obligaba a los ayuntamientos a recibir a regidores que no reunieran alguno de estos requisitos anteriormente citados. Sobre todo, los relativos a la vecindad y a la mayoría de edad.

Con respecto a la vecindad hay que tener en cuenta que el progresivo proceso de privatización de los oficios públicos que se produjo a partir del siglo $\mathrm{xVI}$, hizo posible que accedieran por compra al oficio -bien fuera la venta real o particular- muchos individuos que su interés no residia en ejercer dicho oficio, sino en poseer el título del mismo y así iniciar una carrera política y administrativa, que podía culminar en el desempeño de puestos de responsabilidad en la Corte o en la Administración del Estado. En este caso era habitual que fuera el propio monarca quien eximiese de cumplir este requisito al interesado ${ }^{33}$.

El Libro Verde no dice nada sobre la limpieza de sangre. Quizá porque en Segovia en los siglos XV y XVI tuvieron acceso a las regidurías numerosas familias de origen converso. Es posible que en el mismo Ayuntamiento muchos de sus miembros no soportarían una investigación a fondo sobre el origen de sus familias y de sus fortunas. No obstante, las leyes determinaban que no existía inconveniente para que los cristianos descendientes de judíos pudieran ser admitidos al ejercicio de los oficios públicos, siempre y cuando no hubieran sido penitenciados por el Santo Oficio, pues en este caso no podian serlo ni ellos ni sus descendientes por línea masculina hasta la segunda generación y por línea femenina hasta la primera ${ }^{34}$. De todos modos hemos encontrado noticias sobre la falta de nobleza y limpieza de sangre de uno de los regidores ${ }^{35}$.

Con respecto a la edad había que tener 18 años cumplidos, pero también era habitual que el Rey dispensase de este requisito previa

\footnotetext{
${ }^{33}$ A.M.S., Libro de Actas n. ${ }^{\circ}$ 1019, sesión dei 9-3-1606. Título de Antonio González de

34 Castillo de Bobadilla, Jerónimo de, op. cit., Libro III, cap. VIII, 9.

35 A.M.S., Libro de Actas n. ${ }^{\circ}$ 1004, sesión del 3-9-1576 y 20-11-1576. Sobre la posesión de Aridrés Moreno.
} Proaño 
petición del interesado. En Segovia se llegó a dar el caso de admitir a regidores de 12 años de edad, pero con la facultad de poder acompañar a la Corporación y, a partir de los 14 años, asistir a las sesiones de Ayuntamiento, sin voz ni voto, y así ir aprendiendo el oficio ${ }^{36}$. De todos modos, también se dio el caso de que el Rey supliese la edad al interesado y disfrutase éste de voz y voto a partir de los 16 años de edad ${ }^{37}$.

Lo normal fue que cuando el regidor fuera menor de edad ejerciese el oficio un sustituto en su lugar hasta que el menor cumpliese la edad. Para ello se efectuaba una renuncia "en confianza" en otra persona, con el fin de que el oficio no se perdiera, y cuando el menor cumpliera la edad reglamentaria, esa persona volvería a renunciar a su vez el oficio en el verdadero propietario. En caso de que el periodo de permanencia en el oficio por parte del sustituto fuera muy amplio, se procedía a formalizar un contrato de coadjutor entre las partes ${ }^{38}$. Estos contratos sirvieron de modelo a los contratos de arrendamiento que se empezaron a extender a partir del siglo XVII, cuando la privatización plena de estos oficios dio lugar al desglosamiento de los mismos, separando la propiedad de la titularidad.

\section{c) Incompatibilidades}

Tanto Castillo de Bobadilla como Arias de Verástegui insisten en la incompatibilidad del oficio de regidor con el desempeño de oficios mecánicos, así como con el de escribano o con las actividades mercantiles, pero la realidad fue que las nuevas clases sociales ascendentes representadas por banqueros ${ }^{39}$ y hombres de finanzas, además de mercaderes y fabricantes de paños, vieron abiertas las puertas de la hidalguía y con ella la admisión en los Nobles Linajes, para posteriormente ingresar como regidores en el Ayuntamiento de Segovia. En el vecindario de 1561 hay una larga nómina de mercaderes ricos como

36 Ibidem, Libro de Actas n. ${ }^{\circ}$ 1041, sesión del 19-1-1657. Título de Antonio de Aguilar

37 Ibidem, Libro de Actas n. ${ }^{\circ}$ 1025, sesión del 19-9-1619. Título de Francisco de Tapia Buitrago.

38 Ibidem, Libro de Actas n,.० 1011, sesión del 29-3-1586. Título de Rodrigo de Tordesillas.

39 Quizá deberiamos utilizar el término prestamistas, pues no se trataba de banqueros como lo entendemos hoy en día, sino de hombres hábiles en el manejo de las finanzas, generalmente de origen judío, que actuaban como tesoreros y administradores de la hacienda del monarca. Por supuesto, también adelantaban grandes cantidades de dinero liquido para sutragar las necesidades de la Corona y en pago de estos servicios eran recompensados con oficios públicos. 
Antonio de Peñaranda, Gaspar de Velicia, Esteban de Bonifaz, Antonio de Zamora, Luis de San Millán, Pedro López de Aguinaga, etc., que ingresaron sin mayores problemas como regidores en el Ayuntamiento; $y$ en el vecindario de 1586 observamos que son los fabricantes de paños como Diego López Losa, Antonio de Navacerrada, Gaspar de Salcedo y Andrés Serrano Tapia, etc., los que verán cumplido el mismo objetivo. Lo cual quiere decir que ciertas incompatibilidades, con ayuda de dinero, no eran tan difíciles de superar.

De todos modos, según la ley, era incompatible con el oficio de regidor ser mercader, desempeñar oficio mecánico, ser letrado de ciudad, pertenecer a la orden de caballería de San Juan de Jerusalén, ser escribano o arrendador de rentas reales, tener dos oficios de regidor, ser contador de alcabalas, o tener ciertos impedimentos físicos como ser sordomudo o impedimentos sociales como estar amancebado.

\section{d) Pérdida del oficio}

Eran pocas las causas que podían provocar por sí mismas la pérdida del oficio. Hemos encontrado casos en los que el titular del oficio lo perdía por deudas particulares, pero no es que por este motivo el regidor moroso se viera desposeído del oficio, sino que apremiado por la Justicia - posiblemente por haber presentado el título del oficio como garantía - se veía obligado a venderle para poder satisfacerlas ${ }^{40}$.

Las causas por las que un regidor podía perder su oficio, si exceptuamos la falta de cumplimiento de alguno de los requisitos necesarios para acceder al Regimiento, como podia ser no cumplir los plazos establecidos para presentar las renuncias $-y$ en este caso no significaría la pérdida sino la no admisión-, vienen especificadas en el título.

«... que ecepto en los delitos y crímenes de herexía, de lexa majestatis o el pecado nefando, por ningún otro se pierda ni confisque, ni pueda perder ni confiscar el dicho oficio. $Y$ siendo preciado o yrihabilitado el que lo tubiere le ayan aquel o aquellos que tubieren derecho de heredar en la forma que está dicha..." ${ }^{41}$.

\footnotetext{
40 A.M.S., Libro de Actas n. ${ }^{\circ}$ 1012, sesión del 19-6-1589. Título de Francisco de Mercado y Peñalosa.

41. Ibidem, Libro de Actas n. 1037, sesión del 4-11-1651. Título de Antonio de Contreras.
} 
Así que para perder el oficio había que cometer delitos contra la religión, contra el Rey o contra la moralidad pública.

\section{OFICIOS CON VOZ Y VOTO EN EL AYUNTAMIENTO}

Quienes tenían voz y voto en el Ayuntamiento eran los regidores. O sea que, lo que realmente distinguía a la persona que poseía el oficio de regidor era el derecho a tener voz y voto en las sesiones de Ayuntamiento. Tradicionalmente siempre había sido así, pero las necesidades económicas de la Monarquía, sobre todo durante el reinado de Felipe II, obligaron al monarca a vender oficios públicos que poseyeran este derecho. De este modo, en la segunda mitad del siglo XVI, aparecieron en Segovia los oficios de nueva creación de alférez mayor de la ciudad, regidor fiel-ejecutor y regidor depositario. En la cuarta década del siglo siguiente, se concedieron una serie de títulos que gozaban de ciertas preeminencias que los demás regidores no poseian, lo que resultó inadmisible para el resto de la Corporación. Los interesados tuvieron que renunciar a estos privilegios después de llegar a una concordia con el Ayuntamiento.

\section{a) Alférez mayor de la ciudad}

Sin ninguna duda, el oficio de alférez mayor era el de más alta dignidad y honor dentro del Ayuntamiento. Llevaba aparejado el oficio de regidor, es decir, se cobraba salario por ambas funciones, pero además gozaba de una serie de preeminencias que le distinguian situándole por encima de los demás regidores, como eran el derecho a entrar con armas en las sesiones de Ayuntamiento y tener el mejor asiento y primer voto.

La Corporación se opuso desde un principio a que se acrecentase este oficio, pero, sobre todo, a que recayera en la familia del Conde de Chinchón, pues además de ser nocivo para la ciudad el acrecentamiento de oficios, la familia Cabrera tenía muchos e importantes pleitos entablados desde antiguo con la ciudad, por motivo de usurpación de términos y vasallos pertenecientes a la Comunidad y Tierra de Segovia.

La posesión de este oficio y las preeminencias que disfrutaba ponían en posición de ventaja a los Cabrera sobre la ciudad de Segovia, 
al disfrutar del primer voto y mayor antigüedad en el Ayuntamiento, y la capacidad de influir sobre los demás regidores al disponer del derecho de decretar comisiones y de poder nombrar regidores y jueces para las apelaciones y recusaciones, función que correspondía ejercer al decano o presidente del Ayuntamiento.

Los derechos y obligaciones del alférez mayor venían especificadas en el título ${ }^{42}$. Cada vez que sirviese la ciudad con gente de caballo o a pié, sería misión del alférez mayor encabezar dichas tropas, además de llevar, sacar y alzar el pendón de la ciudad por los reyes en el momento de la sucesión y en las demás ceremonias protocolarias en que se acostumbraba hacer. También se le confiaba la custodia de los «atambores y banderas y pendones y otras insignias" que solía tener la ciudad para acompañar a sus tropas. Se le concedía la posibilidad de poder nombrar teniente o persona que en su lugar desempeñase el oficio, con las mismas prerrogativas y salarios que si fuera el alférez titular. Tanto el Conde de Chinchón como su teniente y después de ellos quienes sucediesen en el cargo, tendrian voto activo y pasivo y las mismas preeminencias que los demás regidores, de manera que para todos los efectos fuera un regidor más, pudiendo entrar en suertes de procurador en Cortes y disfrutar de los demás derechos anexos al cargo. Se le daba el mejor asiento y primer voto, delante de los alcaldes y regidores aunque fueran más antiguos, de manera que después del Corregidor tendría el mejor lugar tanto en los ayuntamientos como en los demás actos protocolarios. El salario a percibir era de 2000 maravedís como cualquier regidor, más otros 2000 mrs. por el oficio de alférez mayor.

Además de todas estas condiciones se le concedía el oficio por «juro de heredad perpetuamente para siempre jamás» lo que le convertía en el primer oficio perpetuo que se otorgó en Segovia.

La oposición por parte de la ciudad fue muy grande, pero el Rey, a través del corregidor, obligó al Ayuntamiento a que diesen por admitido al Conde de Chinchón en el nuevo oficio.

Mientras que quien desempeñó en calidad de teniente el oficio de alférez mayor fue el hijo del Conde no hubo ningún problema. Las

42 Ibidem, Libro de Actas n. 1002, sesión del 27-9-1566. Título de alférez mayor de Pedro Fernández de Cabrera y Bobadilia. 
cosas cambiaron cuando se quiso nombrar como teniente de alférez a una persona ajena a la familia del Conde, algo a lo que se opuso tajantemente la Corporación. Después del pleito correspondiente, se llegó a una concordia con el Ayuntamiento en la que se especificaba que solamente podría ejercer como teniente de alférez mayor el primogénito y heredero en el mayorazgo de la Casa de Chinchón ${ }^{43}$.

\section{b) Regidor fiel-ejecutor}

En Segovia, el oficio de fiel-ejecutor tuvo una vida efímera, pues se acrecentaron dos oficios en el año $1571^{44}$ y se consumieron en $1576^{45}$.

En el título del oficio de fiel-ejecutor vienen especificadas todas las funciones y características del mismo. Se tenían que encargar de controlar la calidad y los precios de todos los mantenimientos que se traian a vender a Segovia, con el fin de garantizar su bondad y justos precios, controlando las posturas que sobre ellos se hacian. Tenían a su cargo las pesas y medidas para evitar todo fraude y engaño y estas debían de ser conforme al patrón que se custodiaba en el Ayuntamiento. Entre las actividades cotidianas estaban las de visitar las carnicerías, las tiendas de los especieros, drogueros, confiteros, así como las que vendian cera, pez, sebo y otras cosas para que en ellas no se vendieran mercancías falsas. Se encargaban de que los taberneros, vinateros, bodegoneros y mesoneros guardasen las ordenanzas y aranceles a los que estaban obligados. Otra de sus funciones era acompañar a los veedores de los oficios artesanos con el fin de garantizar la calidad de las obras de los menestrales. Entre las funciones de policia urbana y buen gobierno estaban las de controlar que las calles, plazas y puertas de entrada y salida de la ciudad, estuvieran limpias y en buen estado de conservación; además de controlar los edificios y las obras particulares para que se realizasen de acuerdo a las ordenanzas. También desarrollaban labores de

\footnotetext{
43 Ibidem, Libro de Actas n. ${ }^{\circ} 1037$, sesión del 24-12-1645 y Leg. XXXI-11.

44 Ibidem, Libro de Actas n. ${ }^{\circ} 1004$, sesión del 21-11-1575. Transmisión del oficio de fielejecutor de Sancho García del Espinar a Gonzalo de Guevara.

${ }^{45}$ Ibidem, Libro de Actas n. ${ }^{\circ}$ 1004, sesión del 10-3-1576. Sobre el consumo de los oficios de fiel-ejecutor.
} 
justicia social, pues se encargaban de intervenir en las derramas y repartimientos juntamente con las personas diputadas para ello, con el fin de que se hicieran justamente y sin agravio para los vecinos. En lo referente a la justicia eran inferiores al Corregidor y sus tenientes, pero cuando estos saliesen a visitar los lugares de la Tierra y jurisdicción de Segovia, podrían acompañarlos e intervenir en todas las cosas tocantes a su oficio y que más atrás han quedado declaras. Según una de las cláusulas del título, los oficios de fieles se deberían seguir desempeñando por las personas que los tuvieren y de la manera que se habían venido desempeñando a lo largo del tiempo, llevando su salario correspondiente y la mitad de los derechos que hasta entonces les había correspondido, y, por supuesto, estando bajo las órdenes de los fieles-ejecutores. Como agentes de la justicia podían perseguir y castigar a los que contravinieren las normas y fueren culpados en las causas que tenían a su cargo, prendiendo y condenado a las penas, así pecuniarias como corporales, en que conforme a las leyes y ordenanzas de la ciudad hubiesen incurrido. Para ello tenían que actuar juntamente con el teniente del corregidor $y$ un regidor nombrado por turno por orden de la justicia; y en caso de que alguno de los dos fieles-ejecutores o el regidor nombrado por la justicia no pudiese asistir por enfermedad o cualquier otra justa causa, lo sentenciase el teniente de corregidor juntamente con los demás asistentes. O sea que, la presencia del teniente de corregidor era indispensable para poder juzgar las causas concernientes al oficio de fiel-ejecutor. En lo que toca a las penas corporales, tan solamente podían imponer penas de azotes y de ahí para abajo; y siendo el delito o culpa merecedor de mayor castigo se remitían a la justicia ordinaria, lo mismo que las apelaciones a ello concernientes.

Además de todas estas obligaciones y derechos inherentes al cargo, tenían el derecho a entrar y asistir a los ayuntamientos juntamente con la justicia y regidores, para hacer relación de lo que al uso y ejercicio de sus oficios tocase, además de tener voz y voto activo y pasivo en todos los asuntos tratados y asiento y lugar en el Ayuntamiento como los demás regidores. De esta manera eran tenidos por regidores y, como tales, debían de cóbrar el mismo salario que los demás regidores tenían establecido; pero, además de ello, por razón de su oficio, cobrarian otros 6000 maravedís más cada año librados de las penas de cámara de la ciudad. A todo esto había que sumar la tercera parte que conforme a las leyes correspondía al juez, repartida por partes iguales entre el teniente de corregidor, los dos fieles-eje- 
cutores y el regidor nombrado por turno para ayudarlos en la celebración de las causas. Por último, además de todo lo dicho hasta aquí, percibirian la mitad de todos los derechos que llevaban los fieles, de las posturas y otras cosas que por razón de su oficio cobraban de acuerdo a las ordenanzas.

Vistos los emolumentos que cobraban los fieles-ejecutores no es de extrañar que la Corporación protestase y estuviese a favor de consumir estos oficios. El Ayuntamiento, tradicionalmente se habia reservado las partes de los derechos de las fieldades, cantidad que iba a engrosar lo que producían los propios y rentas de que disponía; sin embargo, desde la creación de las fieles-ejecutorías, además de no percibir esta cantidad, pues se la repartían por mitad los fieles y los fieles-ejecutores, tenía que pagar los salarios correspondientes a dichos oficios. Así, reunidos la justicia y regidores juntamente con los procuradores del Común, se pusieron de acuerdo para consumir los oficios por compra. Y ya que el Ayuntamiento no tenía con que pagarlos, acordaron que:

"... no hay otra cosa de que más cómodamente se pueda proveer que hechándose por sisa sobre esentos y no esentos, pues es en beneficio común de todos, en los mantenimientos que menos perjuicio hagan.”

Por lo que elevaron una petición al Consejo Real en la que hacian ver que:

"Los dichos oficios de fieles ejecutores con voz y voto en ayuntamiento nuevamente creados, siempre se han tenido y tienen por muy dañosos a la república, e que por esta causa e porque cesen las dichas molestias, daños e inconvenientes que se usarse los dichos oficios se resultan y pueden resultar, les pareció que conviene que se consuman e queden consumidos perpetuamente" ${ }^{46}$.

Producidas las negociaciones se concertaron las partes, el Ayuntamiento por un lado y don Luis de San Milián y don Gonzalo de Guevara por otro, en que el justo precio de cada oficio ascendía a la cantidad de 2200 ducados, lo que suponía 825.000 maravedis en dinero contante.

46 Jbidem, Libro de Actas n. 1004 , sesión del 10-3-1576. 


\section{c) Regidor depositario}

Poco sabemos sobre el oficio de depositario general del Ayuntamiento hasta que no se produjo la creación del oficio capitular de regidor depositario, pues no hemos encontrado ninguna referencia sobre ello. Los primeros Libros de Actas si hacen mención del oficio de mayordomo, pero no citan para nada al depositario general. Desde luego, se trataba de un oficio ligado a la administración y custodia de ciertos caudales del Ayuntamiento. Sin embargo, a principios del siglo XVII, El Libro Verde al hablar sobre la facultad que tienen los regidores para nombrar los oficios de república, dice textualmente:

"Tienen derecho y potestad de elegir dos procuradores en Cortes y otros oficios de la república, como son los letrados de la ciudad; procuradores en ella y en los Consejos y chancillerías; médicos y cirujanos; cambios mayordomos, receptores, tesoreros y depositario general.../... Teniendo Segovia este derecho asentado por leyes y costumbres antiquísimas" ${ }^{47}$.

Las necesidades de la Hacienda Real obligaron a acrecentar oficios de regidor y a crear otros nuevos con voz y voto en el Ayuntamiento. Por esta razón apareció la figura del regidor depositario para que en él se depositaran el dinero y los bienes procedentes de las multas y embargos efectuados por la justicia.

El día 23 de abril de 1569, Felipe II hizo merced de este oficio a Pedro López de Aguinaga. El oficio fue concedido por dos vidas, «que la primera fuese la del dicho Pedro de Aguinaga y la otra la que después dél nombrase o heredase sus bienes" ${ }^{48}$. Poco después, el día 2 de marzo de 1574, éste señor renunció el oficio en Juan de Dueñas. Los trámites fueron largos, pues no se solucionaron hasta el 29 de septiembre de 1576, pero todo se solucionó gracias a los 600 ducados que "para ayuda de nuestras necesidades" entregó Juan de Dueñas a la Hacienda del monarca. O sea que el precio de salida del oficio estaba fijado en 600 ducados o 225.000 maravedís.

\footnotetext{
47. Ibidem, El Libro Verde, cap. II.

48 Ibidem, Libro de Actas n. ${ }^{\circ} 1004$, sesión del 22-10-1576. Título de regidor depositario de Juan de Dueñas.
} 
Se le hacía depositario de todos los depósitos, embargos y secretos de causas civiles y criminales, así como del producto de las multas, bien fueran en dinero o en especie de:

\begin{abstract}
«... pan, vino, bienes muebles y raíces y otros qualesquier género que fuese, hechos en qualquier tiempo pasado o se hiciese de aquí adelante por orden y mandado de la justicia, bien fuese el corregidor o sus tenientes, o qualquier alcalde, o juez o jueces de comisión de los consejos o de qualquier tribunal y ejecutores y jueces de residencia o alcalde de hermandad".
\end{abstract}

O sea que, podríamos decir que se trataba de un mayordomo al servicio de la justicia, con la misión no sólo de percibir y recaudar las sanciones, sino que también tenía que seguir el proceso recaudatorio hasta el final, siguiendo los pleitos que hubiese lugar y entablándolos en caso necesario.

Se le daba la posibilidad de apoderar a una persona que le sustituyera en las funciones de depositario aunque no en las de regidor. De este modo el oficio se desdoblaba en dos que se ejercían por separado y por personas distintas. Requisito imprescindible para poder hacerse cargo de los depósitos, era haber entregado las fianzas «lisas, llanas y abonadas para seguridad de lo en depósito". La cantidad exigida como fianza ascendía a 15.000 ducados, es decir, 5.610 .000 maravedís, lo que suponía una verdadera fortuna, que era renovada cada diez años y durante este tiempo no se le podía exigir ninguna cantidad más ni garantía de ningún tipo.

Se le concedían los mismos derechos que luego tendrán los oficios perpetuos, es decir, que mientras durasen las dos vidas, el titular podría disponer de él como de cualquier otro bien privado, pudiéndolo traspasar, vender o dejar en herencia, contando con que después del segundo poseedor expirase el oficio.

Al tratarse de un oficio por el que habia que entregar fianzas, lógicamente, quien lo desempeñase tendría que poseer los caudales suficientes como para poder afrontarlas con garantías. Esta particularidad hizo que fuera desempeñado por mercaderes y hombres de negocios, que eran quienes disponían de dinero líquido suficiente. Quizá por esto venía expresado en el título:

«... que no se entienda que hayáis de dejar de tratar y contratar en todos los negocios e mercaderías que quisiéredes e por bien tuviéredes, sino que lo podáis hacer e hagáis si quisiéredes libremente sin caer ni incurrir en pena ni caloña alguna". 
En 1609 el Rey concedió a los pueblos, como condición del servicio de millones, la facultad para tomar y consumir los oficios de depositario y de tesoreros de alcabalas y otras rentas, y para nombrar personas que le ejercieran sin voz ni voto en el Ayuntamiento. La ciudad tendría que abonar al propietario la cantidad que éste hubiera pagado en el momento de la compra, aunque si el interesado creyese que llegado el momento de remisión del oficio, éste hubiera alcanzado mayor valor, tendría derecho a exigirlo. El precio que pagó el Ayuntamiento a su propietario por consumir el oficio fue de 1.000 .000 maravedís.

A partir de este momento el oficio de depositario general sería nombrado por los regidores, al igual que los demás oficios no capitulares, por el tiempo que ellos creyesen conveniente y el salario que estimasen oportuno ${ }^{49}$. La duración del contrato quedó fijada en un tiempo de dos años, con un salario de 40.000 maravedís cada año ${ }^{50}$.

\section{d) Oficios con ciertas preeminencias}

En el año 1634, para sufragar los gastos de la guerra en Alemania y Flandes, se acrecentaron dos regidurías con las preeminencias de poder entrar en las sesiones con armas de espada y daga, poder nombrar teniente que las supliera y poder desempeñar a la vez la escribanía del servicio de millones o la tesorería de ellos. Aunque se dio el oficio a los interesados, tuvieron que renunciar las preeminencias de poder entrar con armas y nombrar teniente, pero se les conservaron las de poder ejercer como escribano o tesorero de millones, siempre y cuando pagasen el valor de estos oficios.

Años después, en 1639, se acrecentó un oficio que además de las preeminencias anteriores, se le añadió el título de alcalde mayor o alcalde honorífico, con el privilegio de poder rondar por la ciudad del mismo modo que lo hacía el alguacil mayor. El Ayuntamiento acordó lo mismo que con los dos anteriores, es decir, tuvo que renunciar a todas las preeminencias reservándose únicamente la posibilidad de ejercer como escribano o tesorero de millones.

49 NOVISIMA RECOPILACIÓN, Libro VII, título VII, ley XVI.

50 A.M.S., Libro de Actas n. ${ }^{\circ}$ 1024, sesión del 30-4-1612. 


\section{LA DINÁMICA MUNICIPAL. EL QUEHACER COTIDIANO}

\section{Las sesiones de Ayuntamiento}

El Ayuntamiento, órgano colegiado, era la institución encargada de tomar las decisiones concernientes a la política municipal y sus sesiones suponian la manifestación visible de su funcionamiento. En ellas se trataba todo lo relativo al gobierno y administración municipal.

Las sesiones se celebraban en la Casa Consistorial, comenzando a las 8 de la mañana en verano y las 9 en invierno tras una misa que se celebraba en la capilla oficiada por el capellán del Ayuntamiento. Para el comienzo de la sesión era obligatoria la presencia del Corregidor, o en su caso la de su teniente, y de tres regidores: los diputados del mes y otro más ${ }^{51}$.

Las sesiones se dividían en ordinarias y extraordinarias. Las primeras eran las que se celebraban en los dias y horas fijados por costumbre y, las segundas, las que se celebraban en días y horas inhabituales y, por consiguiente, había que convocarlas.

El escribano del Ayuntamiento encabezaba el Acta indicando el lugar de la reunión, día, mes y año, y, a continuación, el nombre del Corregidor y de los regidores asistentes. El ceremonial que se seguía en las reuniones era siempre el mismo. El asiento de cada uno y la emisión del voto seguía un orden jerárquico determinado por orden de antigüedad. Este protocolo era el reflejo del poder político que ostentaba cada uno y en caso de no cumplirse daba origen a conflictos entre los regidores.

Los regidores segovianos estaban repartidos en dos bancos por mitad, uno de cada linaje: el banco de Día Sanz y el banco de Fernán García. Generalmente, el regidor de nuevo ingreso solía ocupar asiento en el mismo banco que su antecesor en el oficio, pero sentándose en el último lugar. Ser el regidor más antiguo otorgaba un gran honor y numerosos privilegios, por este motivo se seguía rigurosamente el orden de antigüedad.

\footnotetext{
51 Ibídem, Libro de Actas n. ${ }^{\circ}$ 1004, sesión del 4-11-1566.
} 
El número de sesiones que se celebraban al año ni era fijo ni estaba predeterminado. Lo lógico es pensar que si se celebraban dos sesiones semanales, lo normal es que se juntasen 104 días al año.

Se ha realizado un muestreo en once años diferentes guardando una periodicidad aproximada de 10 años.

\begin{tabular}{|c|c|c|c|c|c|c|c|c|c|c|c|c|c|c|c|c|c|c|c|c|}
\hline Año Ses & $\mathrm{Lu}$ & Ma. & Mi. & Ju. & vi. & Sa. & Do. & En. & $\mathrm{Fe}$. & $\mathrm{Ma}$. & Ab. & My. & Ju. & . & $\mathrm{Ag}$. & Se. & Oc. & No. & Di. & Reg. \\
\hline $1560 \quad 102$ & 36 & 13 & 3 & 1 & 36 & 13 & & 10 & 7 & 10 & 7 & 10 & 7 & 9 & 9 & 9 & 8 & 9 & 7 & 30 \\
\hline $1566 \quad 109$ & 36 & 13 & 4 & 3 & 36 & 15 & 2 & 10 & 11 & 11 & 7 & 10 & 6 & 9 & 9 & 10 & 9 & 9 & 8 & 24 \\
\hline $1580 \quad 67$ & & & & & & & & 5 & 5 & 5 & 5 & 7 & 5 & 7 & 5 & & 9 & 8 & 6 & 25 \\
\hline $1590 \quad 91$ & 33 & 12 & 3 & 1 & 29 & 13 & & 11 & 9 & 9 & 7 & 8 & 6 & 7 & 8 & 10 & 5 & 9 & 2 & 31 \\
\hline 160096 & 30 & 13 & 4 & 2 & 36 & 9 & 2 & 9 & 9 & 7 & 5 & 11 & 7 & 9 & 9 & 9 & 8 & 8 & 5 & 24 \\
\hline 1610101 & & & & & & & & 10 & 8 & 12 & 6 & 8 & 6 & 9 & 11 & 8 & 6 & 10 & 7 & 23 \\
\hline 162085 & 25 & 13 & 6 & 1 & 26 & 13 & 1 & 10 & 8 & 6 & 7 & 10 & 2 & 8 & 12 & 8 & 11 & 3 & & 26 \\
\hline $1630 \quad 140$ & 33 & 23 & 19 & 6 & 31 & 23 & 4 & 11 & 8 & 10 & 11 & 11 & 15 & 14 & 13 & 14 & 15 & 10 & 8 & 25 \\
\hline 163895 & 10 & 29 & 10 & 3 & 10 & 32 & 1 & 10 & 7 & 7 & 10 & 12 & 1 & 14 & 9 & 8 & 11 & 6 & & 21 \\
\hline $1648 \quad 96$ & 6 & 33 & 9 & 8 & 6 & 36 & & 8 & 7 & 7 & 6 & 13 & 11 & 10 & 6 & 4 & 8 & 8 & 8 & 26 \\
\hline $1660 \quad 54$ & 6 & 18 & 2 & 3 & 2 & 23 & & 4 & 5 & 2 & 5 & 8 & 6 & 7 & 2 & 6 & 2 & 6 & 1 & 26 \\
\hline
\end{tabular}

Si nos fijamos en el cuadro, los años 1569, con 102 sesiones; 1566 , con 109 sesiones y 1610, con 101 sesiones, se pueden considerar normales en cuando al número de sesiones celebradas. Sin embargo, los años 1590, 1600, 1620, 1638 y 1648, presentan una actividad municipal por debajo de la media con $91,96,85,95$ y 96 sesiones respectivamente. Los extremos vendrían marcado por los años 1630, por un lado, y 1580 y 1660 , por otro. El año 1630 con 140 sesiones es el de más actividad municipal. La explicación quizá haya que buscarla en que los años comprendidos entre 1627 y 1634 fueron los años más dramáticos para historia de la economía segoviana, por lo que no es de extrañar que la actividad municipal se redoblara. Por el contrario, los años 1580 y 1660 marcan los años de menor actividad municipal. La década de los Ochenta del siglo XvI marca el climax de la producción textil y quizá iban tan bien las cosas que no se requería mayor actividad municipal. Sin embargo, el año 1660 es el año de la postración económica. Según los registros parroquiales y los testimonios literarios de la época, los años centrales del siglo xvil fueron los del inicio de una larga decadencia que se prolongó hasta mediados del $x x$, con un ligero repunte en el último cuarto del siglo XVIII y primeros años del XIX, que culminó con la Guerra de la Independencia.

En cuanto a los días de la semana en que se celebraban estas sesiones, estaba estipulado que fuera los lunes y los viernes y en Cua- 
resma los jueves y sábados. Si nos fijamos en el mismo cuadro vemos que esto se cumple con regularidad hasta el año 1630, sin embargo, a partir de éste año la actividad municipal casi se reparte por igual entre todos los días de la semana.

El mes que muestra más actividad es el mes de enero, pues era cuando se repartían las comisiones, y diciembre el que menos. El resto del año se iba repartiendo de forma alternativa.

Por último, en el apartado regidores del mismo cuadro, hemos anotado el número de regidores que asistían al menos una vez al año. Si hallamos la media de los regidores que asistían al menos una vez al año en el periodo contabilizado nos salen, 25,5 regidores. Si exceptuamos los años 1560 y 1590 , en que estuvieron presentes 30 o más regidores (en Segovia había 32 regidores), la asistencia se acercó al $100 \%$ de los regidores; y en el año 1638 asistieron 21 regidores, es decir, el $67 \%$, en los demás casos se observa una presencia del $81,6 \%$ del total, lo cual quiere decir que había un $18,4 \%$ que no asistían a ninguna reunión al cabo del año.

Estos eran los regidores que asistían al cabo del año, pero para saber los que realmente participaban en la vida municipal tenemos que observar el siguiente cuadro.

\begin{tabular}{|c|c|c|c|c|c|c|c|c|c|c|c|c|c|c|c|c|c|c|c|c|c|c|c|c|c|}
\hline Asistentes & 28 & 252 & 242 & 232 & 2120 & & 19 & 181 & 17 & 16 & 15 & 14 & & 12 & 111 & 10 & 9 & 8 & 7 & 6 & 5 & 4 & & 1 & Med. \\
\hline es. 1560 & & & & & & & & & 1 & 1 & 1 & 2 & & 13 & & 12 & 16 & 121 & 15 & 9 & 1 & 3 & & 11 & 9,1 \\
\hline Ses. 1566 & & & & & & 1 & & & & 1 & 1 & & 4 & 1 & & 11 & 14 & 181 & 13 & 16 & 10 & 6 & 6 & & 7,5 \\
\hline Ses. 1580 & & & 1 & & & 1 & 2 & & 1 & 5 & 2 & 5 & 5 & 5 & 4 & 4 & 4 & 5 & 7 & 7 & 4 & 1 & 3 & & 10,1 \\
\hline Ses. 1590 & 2 & 1 & & 2 & 2 & & 1 & 21 & 17 & 3 & 4 & 8 & 5 & 9 & 14 & 9 & 7 & 5 & 3 & 2 & 1 & & & & 14,1 \\
\hline Ses. 1600 & & & & & & & & & 1 & 1 & 1 & & 1 & 4 & 7 & 10 & 9 & 12 & 9 & 15 & 12 & 8 & 3 & & 7,6 \\
\hline Ses. 1610 & & & & & & & & & 1 & & 2 & 5 & 4 & 5 & 5 & 13 & 11 & 15 & 8 & 13 & 9 & 5 & 2 & & 8,1 \\
\hline Ses. 1620 & & & & & & & & & & & 2 & 1 & 1 & 4 & 12 & 10 & 10 & 12 & 8 & 13 & 8 & 2 & 1 & & 8.3 \\
\hline Ses. 1630 & & & & & & & 2 & 2 & 2 & 2 & 3 & 5 & 8 & 12 & 14 & 14 & 18 & 17 & 14 & 18 & 2 & 10 & 2 & & 9,3 \\
\hline Ses. 1638 & & & & & & & & & & 1 & & & 6 & 5 & 11 & 5 & 16 & 11 & 12 & 7 & 5 & 9 & 5 & & 7,5 \\
\hline Ses. 1648 & & & & & & & 1 & 2 & 3 & 3 & 6 & 9 & 8 & 9 & 11 & 10 & 7 & 7 & 7 & 1 & 6 & 1 & 2 & & 10,9 \\
\hline Ses. 1660 & & & & & & & & 1 & 2 & 3 & 4 & 3 & 2 & 8 & & 9 & 3 & 4 & 6 & 4 & 1 & 2 & & 3 & 10.1 \\
\hline
\end{tabular}

En este cuadro hemos anotado el número de regidores que asisten a cada sesión, calculando la media al final del cuadro. Los regidores que verdaderamente asistian y trabajaban para la ciudad, oscilan entre los 7,5 de los años 1566 y 1638 y los 14,1 del año 1590. Hemos calculado la media de los once años tomados en el muestreo y nos salen 9,32 regidores. Esto quiere decir que de 32 regidores que había en Segovia, sólo asistían regularmente el $29,12 \%$ del total. 
En Segovia para poder cobrar el salario de regidor estaba establecida la asistencia a 33 ayuntamientos al año. Si tenemos en cuanta a los regidores que asistieron a más de 30 sesiones, en los años 1560 , 1566, 1580 y 1638 asistieron a más de 30 sesiones 15 regidores, Io que significa un $46,8 \%$; en 1590 , fueron 20 regidores, es decir, un $62,1 \%$; en 1600 y 1610,13 regidores, el $40,6 \%$; en 1620,14 regidores, el $43,7 \%$; en 1630,17 regidores, el $53,1 \%$; en 1648, 16 regidores, el $50 \%$ y en 1660,9 regidores, el $28,1 \%$, lo que nos da una media de 14,7 regidores, es decir, $45,9 \%$ regidores que cobraban su salario, exceptuando los procuradores de Cortes y los regidores al servicio del Rey que también lo cobraban y no asistian al Ayuntamiento.

Si nos fijamos en los regidores que asistían a menos de 10 sesiones al año, número que coincide aproximadamente con las sesiones de carácter extraordinario que se celebraban al año y a las cuales estaban obligados a asistir todos aquellos regidores que se encontrasen en la ciudad y sus alrededores en un radio de 8 leguas, por haber sido citados por los porteros, y hallamos la media de los 11 años del muestreo, observamos que habia un $25 \%$ de regidores que su participación era prácticamente nula. Por lo que podemos decir que se trataba de los regidores que tenían el oficio para aprovecharse del honor y de las preeminencias que llevaba consigo y de la posibilidad de utilizarle como trampolín político hacia la Corte.

Si nos limitamos a contabilizar a los regidores que asistían a más sesiones oscilaban entre 5 y 7 regidores. Hallando la media de los 11 años del muestreo significa que los regidores que más asistían eran el $23 \%$ de todos los que asistían al cabo del año. En definitiva estos eran los verdaderos profesionales de la política municipal y los que más se beneficiaban de las ventajas que reportaba dicha función.

\section{Ámbito de competencias}

Al no haber una ley municipal que regulase las competencias de los municipios, el árnbito material de actuación de los regidores abarcaba desde el funcionamiento del propio Ayuntamiento, hasta la satisfacción de todas las necesidades ciudadanas. Así, los temas tratados en el Consistorio iban desde la elaboración y aprobación de ordenanzas, hasta la resolución de todas las necesidades de los vecinos en lo concerniente a salud pública, asistencia benéfica, moral pública, cos- 
tumbres y cultura; pasando por la ejecución de la justicia, la organización institucional, temas relacionados con la economía de la ciudad y la hacienda del Concejo, urbanismo y policía urbana y todo lo concerniente a la población y vecindad.

El intervensionismo regio se manifestaba, en mayor o menor grado, independientemente del grado de autonomía que aún conservase la ciudad de los tiempos medievales. Una de las manifestaciones de esta autonomía era la capacidad para elaborar y aprobar ordenanzas, pero siempre bajo la supervisión de la Corona. En lo que se refiere al ámbito de la justicia la intervención era más acusada, personificada en el cargo de Corregidor que se atribuía el ejercicio de la jurisdicción civil y criminal. Aunque esto no era óbice para que el Ayuntamiento gozase de cierta actividad judicial, ya que los regidores actuaban como tribunal de apelación de las sentencias dictadas por el Corregidor en cierta cuantía.

En lo concerniente a la organización y funcionamiento del Concejo su autonomía era mucho mayor. Dentro de este campo de actuación hay que incluir el nombramiento de oficios municipales; todo lo relacionado con la población y la adquisición de la condición de vecino; todo lo concerniente a la economía de la ciudad, regulando el abastecimiento de productos de primera necesidad, control de los precios y calidad de los mismos; la regulación de los procesos relacionados con las actividades artesanales y productivas; y las materias relacionadas con el urbanismo, policía urbana y orden público, salud pública, beneficencia, cultura, moral y buenas costumbres, etc.

La administración del patrimonio de la ciudad era otra de las tareas de los regidores. Dicho patrimonio estaba constituido por los bienes de propios ${ }^{52}$ de la Ciudad y los comunes ${ }^{53}$ de la Tierra. La Corporación podía disponer libremente de los propios de la Ciudad, sin embargo, de los comunes de la Tierra solamente le correspondía su administración. Con los rendimientos de los propios la ciudad sufragaba los gastos de su interés particular, como por ejemplo en los salarios de los regidores y los oficiales del Concejo, en fiestas y recibimientos de

\footnotetext{
52 Los bienes de propios abarcaban todo el conjunto de tierras que eran utilizadas por los concejos para la obtención de rentas con las que sufragar los gastos públicos del municipio.

${ }_{53}$ Los comunes eran aquellos bienes rústicos que podían ser utilizados por los vecinos para cubrir sus necesidades.
} 
reyes, en pagar a las milicias de la ciudad, en limosnas a hospitales y monasterios pobres, e, incluso, se podían gastar en sustentar a los regidores que se encontrasen en situación de pobreza ${ }^{54}$.

El producto de los comunes se dedicaba a sostener los servicios públicos cuya utilización y provecho iba en beneficio de los pueblos de la Tierra.

El origen de los bienes de propios y comunes procedía de tiempos de la repoblación tras la Reconquista, cuando se concedieron amplios términos territoriales y la jurisdicción sobre los mismos. Gracias a la riqueza de los pinares de Valsaín el Ayuntamiento podía hacer grandes limosnas con la intervención de los Nobles Linajes.

\section{c) Método de trabajo: las Comisiones. Los regidores meseros}

El Ayuntamiento comenzaba ordinariamente con la lectura de las cartas y provisiones recibidas y, acto seguido, se escuchaban las peticiones de los vecinos y los distintos colectivos residentes en la ciudad. Una vez terminado esto, los regidores proponían todo aquello que considerasen conveniente para el buen gobierno y la consecución del bien público, a la vez que daban cuenta de las comisiones encomendadas. Aunque el Ayuntamiento efectuaba una actividad directa, solía delegar alguna de sus funciones en grupos más reducidos de personas, formando comisiones o nombrando diputados que actuaban en nombre de todos. Estas comisiones se nombraban para abordar tareas específicas y actuaban con plenos poderes en los asuntos encomendados. Las comisiones podían estar formadas por uno o varios regidores y muchas de ellas se nombraban por turno, es decir, siguiendo un orden correlativo. Algunas de ellas, al estar dotadas de cierta remuneración, se echaban a suertes entre los regidores. Para llevar un control de dichas comisiones existía un Libro de Comisiones en el que se anotaban el tipo de comisión y el nombre de los regidores a quienes se había encomendado.

En función al tema del que se ocupasen estas comisiones se podían dividir en ordinarias, extraordinarias y circunstanciales. Las primeras

${ }^{54}$ A.M.S., El Libro Verde, cap. X. 
eran de carácter periódico y se repetían invariablemente pasado un tiempo determinado; estas comisiones se nombraban en el primer Ayuntamiento del año. Las segundas perdían esa periodicidad pero no su cotidianidad, es decir, no se trataba de asuntos nuevos sino que había que resolverlos cuando se presentaban, solían ser de carácter festivo-religioso o recaudatorio y se nombraban en el segundo Ayuntamiento del año. Por último, las circunstanciales eran aquellas que salían sobre la marcha para resolver algún asunto nuevo y específico.

El día 2 de enero de cada año se nombraban comisarios de la ofrenda de Reyes Magos, comisarios de agua y empedrado, diputados de pleitos, comisarios de cuentas de propios, comunes y particulares, comisarios visitadores, comisarios de cartas y de archivo, comisario defensor de ferias, etc.

El día 3 de enero, en el segundo Ayuntamiento del año, se nombraba comisario visitador de millones, diputados de las tabernas de buen vino, diputados de los pueblos, comisarios de toros, comisarios de guardas de los montes, comisarios de carnicerías, tocino, velas, pescado y nieve, comisarios de la alhóndiga y diputados de rentas.

Las comisiones circunstanciales podian tratar sobre el arreglo de puentes deteriorados, reparación de caminos y de la muralla, comisiones para proceder a la información sobre nuevos regidores, comisarios sobre venida de los reyes, comisarios sobre el arriendo de las dehesas, etc.

Una de las comisiones que debía de resultar más lucrativas era la de regidores meseros. Una vez consumidos los oficios de fieles-ejecutores, sus funciones las desempeñaban dos regidores cada mes. Esta era una de las comisiones que se nombraban por turno y en caso de estar ausente quien le tocase, pasaba la vez al siguiente y este último desempañaba dicha función dos meses seguidos. Siendo una de las comisiones que más trabajo daban a los regidores, es de suponer que cuando estos estaban dispuestos a desempeñarla durante dos meses seguidos, era porque los beneficios la harían lo suficientemente atractiva como para soportar ese aumento de trabajo. Entre sus múltiples funciones estaba la de poner los precios de los productos de primera necesidad, mandar limpiar la plaza a los fieles los días de mercado, preocuparse de que se realizasen a su tiempo las obras públicas en las carnicerías, en las panaderías, en el rastro y en el matadero. Tenían que visitar las distintas lonjas de la ciudad, a los obligados de las 
velas, preocuparse de la superintendencia de las obras pías y muchas funciones más relacionadas con la vida cotidiana, que haría esta enumeración interminable si tuviéramos que citarlas aquí todas ellas. Todas estas funciones las desempeñaban acompañados de un alguacil, con vara alta, que actuaba en caso necesario denunciando o deteniendo a los infractores.

\section{EL REGIMIENTO DESDE DENTRO. PERFIL SOCIAL DE LOS REGIDORES}

Durante todo el tiempo que comprende este estudio desempañaron el oficio de regidor nada menos que 290 individuos. Revisando los Libros de Actas hemos encontrado el título de 219 de ellos, de los 71 restantes sabemos de su existencia al haber sido reflejada su asistencia a las sesiones de Ayuntamiento. El primer problema con el que nos encontramos a la hora de confeccionar la lista de regidores fue el de conocer el verdadero nombre de los mismos. Bien es verdad que la mayoría de los casos no ofrecen dudas y siempre se utiliza el mismo nombre y apellidos para referirse a la misma persona, pero es frecuente encontrar distorsiones que confunden el investigador. A lo largo de este trabajo ha sido habitual encontrar el orden de los apellidos invertidos, la omisión de alguno de ellos, la adición de alguno distinto, el cambio de nombre de pila, o, incluso, la utilización del nombre del padre por el del hijo - generalmente por errores del escribano- y viceversa. También nos hemos encontrado a la misma persona con dos identidades distintas.

Ejemplos de lo que acabamos de decir son los casos de Diego Serrano de Tapia y el de sus hijos Francisco y Diego de Tapias Serrano. Ejemplos de apellidos distintos son los de Antonio Zamora, y sus hijos Juan de Dueñas y Antonio de Zamora Osorio. Y el de un apersona nombrada de dos formas distintas es el caso de Jerónimo de Virués que también aparece como Jerónimo de Hoz Arias.

Con respecto a la repetición de nombres y apellidos hay que decir que puede tratarse de la misma persona que ejerce en dos periodos distintos, como son Sancho García del Espinar, Antonio de Guevara, Cristóbal de la Vega Arias, Diego de Avendaño y de la Lama, Juan de Guzmán Becerra, Andrés de Ximena, Gonzalo de Guevara, Francisco de Zuazo y Suárez, Jerónimo de Virués, Alonso González de la Cruz y 
Sancho de Villalva; o también puede tratarse de homónimos como son Diego Arias de Ávila, Luis de Guzmán Becerra, Antonio del Sello, Gaspar de Cuéllar, Juan Ibáñez de Segovia y Antonio Suárez de la Concha.

\section{a) El regimiento desde dentro}

El tiempo de permanencia en el Ayuntamiento no es el mismo para todos los regidores. Sirva como ejemplo de lo que acabamos de decir los casos extremos de Juan Golfín de Carvajal, Gaspar de Guzmán, y Jerónimo de Virués que permanecieron un día como regidores y los de Luis de San Millán o Francisco Arévalo de Zuazo que llegaron a desempeñar el oficio durante 57 años.

Las causas que explican tan poca permanencia en el cargo son variadas: pueden ser simples transmisiones del oficio o tratarse de una operación especulativa, es decir, gente que compraba el oficio para venderlo poco tiempo después a un precio superior.

Si juntamos a los regidores en grupos de 5 en 5 años, según el tiempo de permanencia en el oficio, tenemos: de 1 a 5 años, 84 regidores (28,96\%); de 6 a 10 años, 35 regidores (12,06\%); de 11 a 15 años, 30 regidores $(10,34 \%)$; de 16 a 20 regidores, 18 regidores $(6,20 \%)$; de 21 a 25 años, 16 regidores (5,51\%); de 26 a 30 años, 19 regidores $(6,55 \%)$; de 31 a 35 años, 7 regidores $(2,41 \%)$; de 36 a 40 años, 7 regidores (2,41\%); de 41 a 45 años, 3 regidores (1,03\%); de 46 a 50 años, 1 regidor $(0,34 \%)$; y de 56 a 60 años, 2 regidores $(0,68 \%)$. De 58 regidores no sabemos su tiempo de permanencia al desconoce la fecha de su cese, lo que significa un $20 \%$. Si hallamos la media de permanencia en el cargo de los 232 regidores de los que si tenemos constancia del tiempo de permanencia, nos sale una media de 13,6 años de antigüedad en el cargo.

El número de regidores no fue siempre el mismo. En un principio estuvo formado por 15 regidores, número que aumentó a 24 en el reinado de los Reyes Católicos. Teóricamente este era el número de regidores que estaba establecido para Segovia - así viene especificado en El Libro Verde- pero la realidad fue muy diferente. Tenemos constancia de que a mediados de la década de los Setenta del siglo xvi el número de regidores llegó a alcanzar la cifra de 38, aunque desde estas fechas hasta los años Treinta del siglo siguiente, lo normal fue que oscilara el número de regidores en torno a los 30 . A partir de este 
momento y hasta el año 1753 en que se confeccionó el Catastro del Marqués de la Ensenada, el número de regidores se estabilizó en 32.

De los 290 regidores 213 lo fueron con carácter vitalicio y los 77 restantes lo fueron perpetuos. De estos 213 regidores vitalicios tenemos constancia de que así lo fueron al menos 145 por haber encontrado el título que lo atestigua, aunque es de suponer que los 58 restantes también lo fueran. A esto hay que sumar 3 oficios de regidor depositario, 4 de fieles-ejecutores y 3 de coadjutor, lo que hace un total de 213 regidores vitalicios. Los regimiento perpetuos fueron 77 de los cuales 17 figuran como alquilados y de los 52 restantes, 5 fueron alféreces mayores y de 3 de ellos no tenemos constancia al no haber encontrado el título.

De los 290 oficios, en 104 se produjeron trasmisiones entre familiares $(38,86 \%)$. De estas 104 trasmisiones entre familiares, 59 fueron de padre a hijo $(56,73 \%)$; 2 de hijo a padre (1,92\%); 17 entre hermanos $(16,34 \%)$; 7 entre primos $(6,73 \%)$; 2 entre cuñados $(1,92 \%) ; 7$ de tío a sobrino $(6,73 \%) ; 2$ de abuelo a nieto $(1,92 \%) ; 3$ de suegro a yerno $(2,88 \%) ; 1$ de yerno a suegro $(0,96 \%) ; 1$ casado con su prima $(0,96 \%)$; y 3 de señor a criado $(2,88 \%)$. De las 186 trasmisiones restantes, 2 de ellas fueron oficios desempeñados por teniente, 17 a través de contrato de arrendamiento y 3 por coadjutor. Si descontamos las trasmisiones por arrendamiento y coadjutor, los 164 que quedan podrían tratarse de ventas entre particulares, aunque tenemos constancia de algunas de ellas fueron renunciaciones "en confianza", es decir, una fórmula utilizada como modo de trasmisión entre particulares para que no se perdieran los oficios. Presumimos que este tipo de trasmisiones debió de ser muy frecuente, recurriendo el poseedor de un oficio a algún familiar, deudo o amigo para que sirviera de intermediario entre, por ejemplo, un padre y un hijo menos de 18 años, sirviendo el oficio hasta que el menor alcanzase la edad para poder servir el oficio. Este tipo de trasmisiones se realizaron sobre todo en la segunda mitad del XVI y las primeras décadas del XVIl en que estuvieron prohibidos los arrendamientos. ¿Se trataría de operaciones de arrendamiento encubiertas? Posiblemente.

Con respecto a la movilidad existente en cada oficio se han podido reconstruir 19 series completas. El número de sucesiones oscila entre 5 y 11, muchas de ellas entre miembros de una misma familia. En algunos casos se observa la presencia de un extraño entre dos de ellos por un breve periodo de tiempo, suponiendo que estos casos son esa clase de trasmisiones que se hacían "en confianza". 
Perfil social de los regidores

La mayoría de los regidores no tenían una profesión claramente definida, es más, en los vecindarios lo que principalmente se recalca es su condición de regidor. Como si el desempeño de este oficio borrara el pasado de estos individuos. Generalmente vivían de sus rentas y el cargo de regidor les definía socialmente.

Los que habían conseguido hacer fortuna a través del ejercicio de la mercaduría comercial o manufacturera, procedían a una reconversión de su actividad con el fin de eliminar en lo posible las pruebas que declaraban sus orígenes. Muchos de los regidores reunían conjuntamente las características o desempeñaban las funciones propias de varias profesiones a la vez, es decir, podian ser caballeros, con título universitario, rentistas y terratenientes y desempeñar un oficio en la Administración. Los habia de procedencia burguesa y con ocupaciones propias de este grupo social: mercaderes, tratantes, artesanos fabricantes todos ellos con prestigio social y éxito profesional reconocido; los había que procedian del mundo universitario: doctores, licenciados - en leyes fundamentalmente- que ejercían como burócratas, escribanos, procuradores, administradores de rentas y en cualquier puesto de la administración pública; y los había, sobre todo, de procedencia caballeresca.

Desde los tiempos de la repoblación de la ciudad los regidores habían pertenecido al estamento militar y caballeresco, con una pequeña representación del pueblo llano que enseguida trataban de incorporarse al estamento superior. Pero esta clase caballeresca siempre fue muy permeable a todos aquellos que su capacidad económica les permitiera mantener armas y caballo. A lo largo del tiempo, gentes adineradas cuyos ingresos procedían del ejercicio de actividades típicamente burguesas, habían reclamado para sí el derecho a gobernar junto a la caballería tradicional, adoptando para ello los modos y formas de vida caballeresca.

Entre las formas de ascenso social más rápida se encontraban el desempeño de la privanza y la exención de impuestos. Un modo rápido y sencillo de conseguir la privanza siempre fue el préstamo y la administración de los caudales de la Corona; y para conseguir la exención de impuestos, el desempeño de un oficio en la Casa de la Moneda.

La ciudad había crecido al amparo de una oligarquía social de corte militar y caballeresco, dejando al margen de toda actividad política a 
los hidalgos de sangre y solar conocido. Esto no quiere decir que los caballeros no fueran hidalgos, sino que para ellos el reconocimiento de la hidalguía era un título adicional. Las transformaciones que se produjeron en los ejércitos y el abandono de las prácticas militares por parte de los caballeros segovianos, desapareciendo de la vida cotidiana de la ciudad los alardes y los desfiles militares, tuvieron una gran influencia en los cambios de los valores y de la imagen social de los caballeros, pues como consecuencia de ello perdieron su referencia más genuina ${ }^{55}$. La razón no era otra que, como consecuencia de haber dado entrada a lo largo del siglo xvi en la Junta de Nobles Linajes y en el Regimiento a gentes adineradas procedentes del mundo comercial e industrial, cuya justificación para la posesión de armas y caballo se debía más a la necesidad de hacer ostentación de su riqueza que al verdadero sentimiento de pertenencia al estamento caballeresco, la pérdida de los valores propios había dejado al estamento militar vacío de contenido.

De los 290 regidores que hemos contabilizado 152 eran caballeros pertenecientes a los Nobles Linajes $(52,41 \%), 53$ poseían título universitario $(18,27 \%)$ - su procedencia podía ser de familias tanto burguesas como caballerescas-, 14 vivían de sus rentas $(4,82 \%), 15$ se dedicaban a actividades ganaderas $(5,17 \%)$, y 57 a actividades propiamente burguesas $(19,65 \%)$.

De los 57 miembros de la burguesía $36(63,15 \%)$ eran mercaderes y $21(36,84 \%)$ hacedores de paños. En el siglo XVı se contabilizan 24 mercaderes y 5 fabricantes; en el siglo XVII se invierten los términos e ingresan 16 fabricantes por sólo 12 mercaderes. Hay que tener en cuenta que estas cifras se refieren a la primera generación, pues como para entrar en el Regimiento tenían que haber sido recibidos como caballeros en los Nobles Linajes, sus hijos, se dedicasen o no a las mismas actividades que los padres, estaban considerados desde un principio como caballeros. Lo cual quiere decir que si nos atuviéramos a los orígenes de los regidores, el porcentaje de los miembros de la burguesía sería mucho mayor y descendería en la misma proporción el de caballeros.

55 A.M.S., Libro de Actas n. ${ }^{\circ}$ 1003, sesión del 12-9-1572. En este día se da cuenta sobre el contenido de una carta del Rey en la que se decía que muchos nobles estaban desarmados y sin caballo, y los pocos que aún los conservaban estaban tan faltos de ejercicios militares, que cada día, tan loable práctica, iba en mayor disminución y quiebra. 
Tenemos constancia de que de los 290 regidores $12(4,13 \%)$ estaban en posesión de un título de nobleza, $10(3,44 \%)$ eran señores jurisdiccionales y $174(60 \%)$ fueron recibidos en los Nobles Linajes. De los 116 que no tenemos datos, $68(58,62 \%)$ llevan apellidos de familias tradicionales de Segovia, por lo que podemos presumir que se trataba de caballeros aunque no hubiesen sido recibidos en los Nobles Linajes; 6 de ellos figuran como rentistas $(5,17 \%), 20$ pertenecían al mundo de la artesanía o del comercio $(17,24 \%)$ y los 22 restantes pertenecían al mundo universitario $(18,96 \%)$. Ahora bien, de los 174 que sí fueron recibidos en los Nobles Linajes, 99 lo fueron antes de ingresar en el Regimiento $(56,89), 71$ después de ser admitidos como regidores $(40,80 \%)$ y 4 en el mismo año de su ingreso en el Ayuntamiento $(2,29 \%)$.

Por último, tenemos que decir que, recibidos o no en los Nobles Linajes, el título de regidor llevaba implícita la categoría de caballero.

Después de lo dicho hasta aquí cabe preguntarse sobre la opinión que mantenía los hidalgos de sangre y solar conocido, y que quedaban al margen de la alta sociedad segoviana de la época, sobre los regidores. El testimonio nos le facilita la "Cofradía de los Hijosdalgo" cuya sede social estaba en la iglesia de San Millán:

"Que aviéndose movido antiguamente un pleito muy grande entre los Caballeros Hijosdalgos desta ciudad, que tenian cierta Cofradia en que no se permitía entrar otros que no fuesen hijosdalgos de sangre, incluyendo los regidores de Segovia, de que resultó prender a todos los cofrades por blandón y desprecio que avian querido hacer a los dichos regidores, motejándoles de hombres bajos..." ${ }^{56}$.

El texto es revelador de la opinión que tenían los hidalgos de Segovia sobre el origen social de los regidores segovianos.

En cuanto a los regidores que lograron vestir algún hábito de caballero de alguna de las Órdenes Militares, hemos contabilizado 58 $(20 \%), 27$ de ellos $(9,31 \%)$ antes de ser regidores y los 31 restantes $(10,68 \%)$ después de su ingreso en el Ayuntamiento. A la Orden de Santiago pertenecieron $36(62,06 \%)$, a la Orden de Calatrava 11 $(18,96 \%)$, a la Orden de Alcántara $10(17,24 \%)$ y a la Orden de San Juan un regidor.

56 LaRios Martín, J., Nobiliario Segoviano. I, pp. 237/238. 
De los 290 regidores 49 estuvieron al servicio de S. M., y de entre ellos, 31 gozaron de algún hábito de caballero. Lo cual quiere decir que el $57,44 \%$ de los caballeros de hábito llegaron a su vez a desempeñar algún oficio al servicio de la Corona. Los que se encargaban del servicio personal del Rey como pajes, criados, caballerizos o mayordomos, o bien eran nobles titulados o bien gentes de fuera de Segovia, lo cual quiere decir que estos individuos fueron cortesanos antes que regidores. En este sentido siguieron el camino opuesto a todos los demás regidores, pues lo normal era que primero se accediera al oficio de regidor y después tratasen de alcanzar el ascenso social a través del servicio real. Como norma general, los que consiguieron mercedes de capa y espada o de carácter militar, es decir, corregimientos, adelantados o gobernadores, eran del estado caballeresco; sin embargo, los puestos de la Administración, bien como tesoreros, fiscales o puestos en los Consejos, quedaban reservados para los pertenecientes al grupo de los titulados universitarios.

Además, 56 regidores tuvieron la suerte de desempeñar como procuradores en Cortes y 7 de ellos como diputados del Reino. De los 56 procuradores en Cortes vistieron hábito de caballero solamente 15 , siendo 41 los que a pesar de poder hacerlo no solicitaron ese galardón. Esta es una prueba concluyente de que los orígenes de los regidores, tanto familiares como el de sus fortunas, no estaban en condiciones de aguantar la investigación requerida, a no ser que dispusieran de grandes fortunas personales y recurriesen a la compra de testigos falsos.

Por último, tenemos que decir que no todos los regidores disfrutaron de una posición desahogada. También los hubo que vivieron sino en la pobreza, sí con muchas dificultades económicas. Este fue el caso de Gutierre Pantoja de Monroy, Antonio de Prado y de Francisco Asenjo Osorio. Estos tres caballeros regidores fueron enterrados por la noche por ser pobres y no tener para la pompa que pedia su posición social. La vida de caballeros y la necesidad de guardar las apariencias, obligaron a alguno de ellos a endeudarse y morir en la miseria ${ }^{57}$.

57 Parroquia de la Santisima Trinidad. Libro de difuntos de la iglesia de San Facundo de 1663 , y los libros de difunto de la Santísima Trinidad de 1685 y 1693 , respectivamente. 
c) El ascenso social

c.1. Procurador del Común.-Los regidores pecheros, mientras los hubo, siempre habían sido elegidos de entre los más ricos y de mayor calidad del Común de vecinos de la ciudad. Una vez cerrada esta puerta de ascenso social para esta clase burguesa y con ella la participación directa del Común de la ciudad en la política municipal, la única presencia del pueblo llano en el Ayuntamiento quedó limitada a la participación con voz pero sin voto de los procuradores del Común. En este caso también estos representantes del pueblo se extrajeron de entre los más ricos e influyentes de los pecheros.

"Los procuradores del Común... son siempre personas desinteresadas y ciudadanos honrados, y se nombra cada año uno, y cada uno dura dos años, siendo de la ciudad el uno y el otro del arrabal, y tiene el de la ciudad el mejor asiento de los dos" ${ }^{58}$.

A lo largo del siglo XVI son múltiples los casos que encontramos de estos individuos que buscan en el ejercicio de la representación del Común, la plataforma de lanzamiento hacía el estamento superior de los caballeros. Cristóbal Suárez de la Concha, procurador del Común en 1542 y regidor en 1572; Gaspar de Cuellar, procurador del Común en 1559 y regidor 1571; Antonio Suárez, procurador del Común en 1576 y regidor a finales del mismo años; Andrés Serrano Tapia, procurador del Común en 1582 y regidor en 1596; y Antonio de la Peña, procurador del Común en 1589 y regidor en 1609.

Pero generalmente no bastaba con ser procurador del Común para acceder a una regiduría. Este oficio les ponía en contacto con los regidores, les facilitaba el establecimiento de relaciones de amistad y trato social y les hacía participar en las fiestas y actos públicos mezclados con los caballeros. Después, amparándose en este trato y en sus grandes fortunas, solían emparentar con los miembros de la caballería tradicional - a través de los lazos del matrimonio-, ingresaban en los Nobles Linajes y, una vez reconocidos como caballeros, accedían al oficio de regidor.

También hemos observado como a principios del siglo XVII, el oficio de depositario general del Ayuntamiento sirvió para conseguir los mis- 
mos objetivos. En 1610 el licenciado Manuel Martínez era depositario general y en 1611 dimitió como tal para ingresar como regidor.

c.2. Los Nobles Linajes.-Esta institución agrupaba en su seno a los caballeros segovianos y al ser Segovia una ciudad de behetría, no había en ella más acto de nobleza que pertenecer a la Junta de Nobles Linajes. En ella estaba incluidos tanto la vieja nobleza urbana terrateniente, como algunos hidalgos sin fortuna dedicados a la vida militar. Pero en el siglo XVI esta institución fue muy permeable a la entrada de nuevos ricos cuyos medios de vida nada tenían que ver con la práctica militar. Parece ser que en 1531 había 1013 personas recibidas en los Nobles Linajes, un número demasiado elevado con respecto al número de vecinos pecheros. Como consecuencia de ello se levantaron airadas protestas de los procuradores del Común y aunque a partir de 1585 se produjo una reacción nobiliarista dentro de la Institución, aún continuaron entrando nuevos ricos de forma irregular.

Aunque no hemos encontrado ningún expediente personal de los que se abrian a los pretendientes en el momento de su ingreso en la Institución, si hemos visto las ordenanzas en las que se regula el sistema de ingreso. Según éstas no podía ser recibido quien no fuera hijodalgo por línea de varón, ni ninguna persona que tuviera o hubiese tenido oficio mecánico o haber sido examinado en él aunque no lo usase ${ }^{59}$. Pero estas ordenanzas se convertían en papel mojado si se trataba de aspirantes con grandes fortunas. Gaspar de Oquendo Lebrón, procedente de una familia de mercaderes, fue admitido por su habilidad como caballista participando en los alardes y juegos militares organizados por los caballeros.

Pero no había que ser un hábil caballista para ser considerado caballero. Lo verdaderamente importante era la ostentación, hacer alarde de riqueza y tomar los hábitos y costumbres caballerescas.

En la información hecha sobre la nobleza de Pedro Meléndez Ayones, como pretendiente a un hábito de caballero de órdenes, se tuvieron en cuenta estos de talles de apariencia externa y fueron tenidos como prueba de nobleza, por lo que es de suponer que para el ingreso en los Nobles Linajes se siguieran procesos similares. En este caso los testigos dijeron que aunque era notorio que el padre del preten-

59 A.M.S., Nobles Linajes, caja n. 2, Libro de Acuerdos 1602-1637, fols. 5 al 11. 
diente había administrado lanas de sus ganados por medio de capataces y oficiales asalariados, teniendo su fábrica en el arrabal y su casa en el recinto amurallado, donde vivía "con lustre y fasto de criados, teniendo coche de cuatro mulas y concurriendo a las funciones públicas de estimación junto a los demás caballeros" ${ }^{60}$, eran tenidos por hidalgos y limpios de toda raza. Al tratar de las funciones que se realizaban en su fábrica de paños, se especificaba que eran labrados por maestros y oficiales, y entre otras cosas alegaba en su defensa:

"Que esta granjería de paños la tenían y habían tenido desde antiguo personas de la misma calidad que el pretendiente, canónigos, viudas ricas y caballeros $"{ }^{61}$.

Lo cual prueba que en el obraje y comercialización de los paños estaban implicados todas las clases sociales de la ciudad.

Una de las conclusiones que se sacan a partir de esta información es la de que este proceso de ennoblecimiento basado en la apariencia social, siempre se daba en las segundas generaciones, es decir, se alude al padre del pretendiente como a la persona a la que afectaban estas labores, pero no al pretendiente.

"Que el padre del pretendiente tenía armas y caballos y muchos testigos le vieron intervenir en regocijos y juegos de cañas y tratarse con los demás caballeros hijosdalgos de la ciudad» 62 .

El origen familiar y de la riqueza de estos nuevos ricos daba lugar a toda clase de elucubraciones por parte de los testigos y parece ser que eran pocos los que estaban de acuerdo en que se removiera en la ascendencia de sus antepasados. El hecho de emparentarse y casar a sus hijos con las hijas de los de los miembros de las familias tradicionales segovianas, facilitaba estos procesos de ennoblecimiento, pues, al fin y al cabo, cada uno aportaba al matrimonio lo que la otra parte deseaba: dinero por una lado y nobleza por otro.

Lo que sí es cierto es, que, bien de una manera o bien de otra, estos advenedizos lograban sacar adelante dichos procesos de información y se hacian con la nobleza tan deseada. Nuca fue fácil hacer-

Larios Martín, J., op. cit., III, p. 327.

Ibidem.

Ibidem, tomo IV, pág. 131. 
se con las pruebas de hidalguía sin ser merecedores de ellas, pero, debido a las necesidades de la Hacienda pública, en el periodo que nos ocupa se vendieron indiscriminadamente y los burgueses tuvieron oportunidad para hacerse con oficios, rentas, vasallos y jurisdicciones aprovechando las continuas crisis de la Corona.

c.3. Procuradores en Cortes.-Los procuradores en Cortes servían de cauce ante la Corona para exponer los intereses de la oligarquia ciudadana. El desempeño de esta función, además de significar un honor, era muy ventajosa por los beneficios que reportaba: sueldos y ayudas de costas, mercedes, libranzas, hábitos de caballero, oficios cortesanos o en la Administración, juros, etc.

La rigurosidad que se seguía en los procesos de información abiertos para el ingreso en alguna de las Órdenes Militares, provocó que muchos procuradores en Cortes segovianos - provenientes de familias burguesas de orígenes oscuros - no se arriesgaran a solicitar el hábito, a no ser que sus fortunas fueran verdaderamente importantes. De todos modos, 14 de los 57 procuradores en Cortes por Segovia lograron un hábito de caballería y 10 de ellos, ocuparon puestos en la Administración.

c.4. Hábitos de caballero de Órdenes Militares.-Fueron muchos los regidores que pusieron todo su empeño en lograr un hábito de caballero. Al principio la consecución de un hábito de caballero era difícii -para conseguirlo había que probar servicios prestados a la Corona, además de pasar las pruebas de información necesarias- pero en el siglo XVII era tal la cantidad de hábitos que se habían concedido, que se devaluó bastante el valor, el prestigio y el honor que representaba la posesión de dicha distinción, por lo que dentro de la tendencia refeudalizadora que se produjo en la sociedad, se hicieron más rigurosos y exhaustivos los procesos de información para la obtención del hábito.

Para la consecución del hábito el pretendiente presentaba una genealogía que tenía que retrotraerse hasta la tercera generación como mínimo y los méritos que le reconocieran como merecedor del mismo. Dicha genealogía se comprobaba examinado los archivos parroquiales y se aseguraba con el examen de los testamentos en los oficios de los escribanos. En cuanto a la nobleza, y en el caso particular de Segovia, se comprobaba a través de los libros de la Junta de Nobles Linajes, donde quedaba recogido que el pretendiente y sus antecesores gozaban de exenciones propias de los hijosaalgos de sangre. 
Los requisitos para el ingreso eran: ser hijo legítimo y de legítimo matrimonio; de notoria hidalguía y limpieza de toda mala raza de moros y judíos y conversos hasta la tercera generación, y no contar entre sus antepasados directos hasta el cuarto grado con penitenciados, reconciliados o sospechosos de herejía; no haber desempeñado ellos ni sus antepasados oficios viles ni mecánicos, ni haber ejercido como mercader o prestamista; $y$, por último, no estar infamado el pretendiente.

Como en el caso de la consecución de hidalguía la riqueza influyó mucho en la concesión de un hábito, pero siempre existió más rigurosidad para entrar en las Órdenes Militares que para entrar en el Santo Oficio.

c.5. Señoríos y títulos de nobleza.-Este era el sueño de todo regidor, pues si el oficio municipal suponía el inicio de la carrera política y social, llegar a alcanzar un título de nobleza era la culminación de la misma. En el Regimiento de Segovia se han contabilizado 12 nobles titulados y 10 señoríos jurisdiccionales.

Durante la segunda mitad del siglo XVI los únicos nobles titulados en el Consistorio fueron los diferentes Condes de Chinchón. En cuanto a los señoríos se cuentan al menos 5 señoríos jurisdiccionales en el mismo periodo.

En el siglo XVII aumentó el número de titulados hasta 10, sin embargo el número de señores permaneció estable con un total de 4 señores jurisdiccionales. Lo que se observa es que algunos de estos individuos después de alcanzar el señorío, bien ellos mismos o bien sus hijos, con el tiempo alcanzaron titulo de nobleza con el mismo nombre que el señorío.

Indudablemente, todos estos individuos además de los títulos y señoríos, alcanzaron importantes puestos cortesanos como criados de los reyes o en la administración del Estado.

\section{LA REPRESENTACIÓN DE LA CIUDAD ANTE LAS CORTES}

\section{a) Los procuradores en Cortes}

Con el término de procuradores en Cortes se conocía a los representantes del tercer estado en las Cortes de los antiguos reinos de Castilla. La ciudad a la que representaban les otorgaba un poder, que 
a su vez servía de credencial para poder ser recibido en las Cortes, para que actuara en nombre de ella. En esta carta de poder quedaba especificada la capacidad de decisión y los límites de libertad de que gozaban los procuradores en el ejercicio de sus atribuciones.

Las Cortes fueron asambleas políticas convocadas y presidas por el Rey en las que participaban los tres estamentos. Sus competencias comprendían tanto el juramento de fidelidad al Rey o a su heredero, así como la votación de servicios y la discusión de cuestiones políticas y económicas. A partir de las Cortes de 1538 se dejó de convocar a los nobles y eclesiásticos quedando solamente constituida la asamblea por los representantes del tercer estado.

El Rey era quien convocaba las Cortes y fijaba las condiciones y las calidades que tenían que reunir los representantes de los ciudadanos, limitando para este fin a los caballeros y escuderos reconocidos como regidores. En cuanto a la autonomía de los procuradores a la hora de tomar decisiones en nombre de la ciudad cambió según las épocas. Hasta el siglo XV casi siempre el poder fue imperativo, sin embargo, en los siglos XVI y XVII se fueron alternando tanto el poder consultivo como el poder decisivo.

La carta de convocatoria dirigida por el Rey al Concejo anunciaba la fecha y el lugar donde se iban a celebrar las Cortes, indicando los motivos que le movían a celebrarlas. Una vez notificado esto, mandaba elegir los procuradores que habían de representar a la ciudad.

El ceremonial a seguir era siempre el mismo: el Corregidor reunía al Ayuntamiento y se procedía a citar a los regidores ausentes de la ciudad, pues para no perder el derecho a ser elegidos, era imprescindible hallarse presente en el Ayuntamiento el día en que se procedía a echar las suertes. Paralelamente a todos estos trámites, se recibían en el Ayuntamiento diferentes escritos remitidos por el Rey, en los que se pedía que diera por presentados en dicho sorteo a todos aquellos regidores que estuvieran fuera de la ciudad al servicio de la Corona. El sistema de elección consistía en confeccionar unas papeletas con el nombre de todos los regidores que se introducían en un cántaro; del mismo modo, se elaboraba igual número de papeletas en blanco menos una, en la que ponía la palabra «procurador en Cortes». Una vez introducidos los dos tipos de papeletas en sus respectivos cántaros, se llamaba a un muchacho para que fuera sacando una cédula de cada cántaro y se las fuera entregando al Corregidor y al regidor más antiguo. Esta operación se repetía las veces que fuera necesario 
hasta que saliese el nombre de un regidor y coincidiese con la que ponía "procurador en Cortes". Acto seguido la ciudad otorgaba el poder a sus procuradores.

Como prueba de la importancia que tenía para los regidores la posibilidad de ser elegido procurador en Cortes, hemos observado que a las sesiones en que se celebraba el sorteo se hallaban presentes la inmensa mayoría de los regidores existentes en la ciudad.

En la cédula de la convocatoria se precisaba siempre que el poder otorgado tenía que ajustarse a un "poder bastante", es decir, libre de cualquier atadura y de todo aquello que impidiera cumplir con la voluntad real. Pero las ciudades, en la segunda mitad del siglo XVI y las primeras décadas del XVII, casi siempre apoderaron a sus procuradores con un poder consultivo, lo cual ocasionó fuertes enfrentamientos entre las ciudades y la Corona.

Las fórmulas de la convocatoria eran aceptadas por las ciudades aunque procedían a su referendo en un intento de demostrar su autonomía. Las necesidades hacendísticas de la Corona provocaron que por parte del Rey se recurriera a todos los mecanismos posibles para que sus peticiones fueran aceptadas. Uno de ellos fue la concesión de mercedes a los procuradores en función de la resistencia que hubiesen presentado a la voluntad real. En respuesta a esto, en Segovia se tomaron las debidas precauciones con el fin de evitar el posible "transfuguismo" de sus procuradores. Estos tuvieron que someterse a pleito-homenaje y a una serie de limitaciones a la hora de emitir su voto, obligándoles a consultar a la ciudad siempre que hubiera una alteración que estuviera en contra de lo convenido.

El acta de poder iba firmada por los regidores asistentes a la reunión, por los procuradores del Común y por los procuradores de la Tierra y el Presidente de las Cortes podía o no aceptar las fórmulas utilizadas.

Los problemas comenzaron a partir de las Cortes de 1563, cuando en las de 1566 y 1570 se exigió a las ciudades un poder suficiente y sin reservas para aprobar las proposiciones de la Corona. En las Cortes de 1575 se les dio total libertad a los procuradores, sin embargo, en 1579, al desbordar las peticiones del monarca las posibilidades económicas de la ciudad, se les negó el poder decisivo a los procuradores. El Rey no estaba dispuesto a consentir la rebeldía de las ciudades y ordenó a los corregidores que encarcelaran a los regido- 
res que se opusieran al poder decisivo mientras no depusieran de su actitud. A partir de estas Cortes se comenzó a repartir entre los procuradores ciertas cantidades de dinero en concepto de ayudas de costas.

Este enfrentamiento entre las ciudades y la Corona se saldará, con el tiempo, con la satisfacción por parte de las ciudades de las necesidades de la Corona, pero a cambio de permitir el monarca el asentamiento definitivo de la oligarquía de los regidores como detentadores en exclusiva del poder municipal. Se permitía el intervensionismo regio en la política municipal, aumentando el centralismo de gobierno en detrimento de los restos de la vieja autonomía concejil medieval, pero a la vez perpetuaba la posición preponderante de unas pocas familias al frente de los destinos locales, gobernando a su antojo y en satisfacción de sus propios intereses ${ }^{63}$.

Dentro de este marco de relaciones entre la Corona y las ciudades, el Corregidor, funcionario al servicio de la corona, ocupaba un papel muy importante. Por mandato del Rey debía de tratar de influir en las decisiones de los regidores por todos los medios legales a su alcance, utilizando, sobre todo, la diplomacia; pero hubo algunos que, prestos a servir al Rey, tampoco dudaron en recurrir a todo su poder y al de la fuerza y las amenazas en caso necesario.

En las primeras décadas del siglo XVII, debido, quizá, a la corriente pacifista que caracterizó el reinado de Felipe III, se redujo la presión sobre los procuradores por parte de la Corona y estos volvieron a gozar del poder consultivo. Pero en la tercera década del siglo comenzaron a cambiar de signo estas relaciones. Primero se utilizará la diplomacia y las dádivas, después, no se dudará en utilizar la fuerza. Así sucedió a partir de las Cortes de 1632 en que se obligó a las ciudades a dar a sus procuradores un poder decisivo. En caso contrario, los regidores que se opusieran a los deseos del monarca, serían encarcelados, despojados de sus oficios y multados con 1000 ducados para la Cámara ${ }^{64}$. Aunque más de la mitad de los regidores se opu-

\footnotetext{
63 La concesión del derecho a poder renunciar sus oficios de regidor, en vida o en muerte, a los procuradores en Cortes que hubiesen estado presentes en el juramento del príncipe heredero, hay que inscribirle dentro de este proceso de patrimonialización de los oficios en manos de las oligarquías urbanas, que de este modo se perpetuaron en los oficios y aseguraban en ellos a sus herederos.
}

64 A.M.S., Libro de Actas $n{ }^{\circ}$ 1033, sesión del 1-2-1632. 
sieron a los deseos del monarca, ante las amenazas del Corregidor y después de haber sido encarcelados y despojados de sus oficios, se avinieron a firmar el poder exigido por el Rey.

A partir de esta fecha en todas las convocatorias de Cortes se exigirá el poder decisivo.

Pero para darnos cuenta de la verdadera dimensión del grado de intervención del monarca en la política municipal cuando se trataba de defender sus intereses, es paradigmático el ejemplo de lo que sucedió en el año 1645. El día 16 de septiembre de dicho año se leyó una carta del Presidente de Castilla sobre el servicio de los 3 millones. Se citó a los regidores para tratar sobre ello, pero al haber llegado a oídos del Rey que el Corregidor de la ciudad se ponía al lado de los regidores y en contra del monarca, se dio orden al señor don Pedro de Munive, del Concejo de S. M. y Oidor de la Chancillería de Valladolid, para que asistiera como presidente a las sesiones del Ayuntamiento de Segovia en detrimento del propio Corregidor de la ciudad. Pedro de Sanzoles, que así se llamaba el Corregidor de Segovia, conocedor del estado de pauperización de la ciudad, se había puesto del lado de los regidores y en favor de la ciudad, faltando a su obligación de estar al lado de la Corona, por lo que el monarca no dudó en sustituirle temporalmente con el fin de conseguir sus objetivos.

La actuación de las Cortes en materia de concesión de servicios fue siempre demasiado dócil a los intereses de la Monarquía. Los reyes siempre supieron manejar los resortes necesarios para tener dominadas las Cortes. Además de inmiscuirse en los asuntos municipales a través de una intensa centralización política, jamás antepusieron las peticiones de las ciudades a la concesión de los servicios. Las pretensiones de la Corona fueron mantener contentos a los procuradores concediéndoles las peticiones a las que tenian derecho a efectuar y gratificándoles con amplios beneficios económicos.

El salario que pagaba la ciudad de Segovia a sus procuradores en Cortes en 1542 era de 10 reales, es decir, 340 maravedís. El gran desembolso que suponía pagar estos salarios tras una larga permanencia en las Cortes, ponía en aprietos las arcas de la ciudad, que disponía de muy pocos bienes de propios que era de donde se pagaban estos salarios ${ }^{65}$.

65 Ibidem, Libro de Actas n. ${ }^{\circ} 1000$, sesión del 2-6-1542. 
En 1578 se subió el salario de los procuradores a razón de 500 mrs. diarios, desde el día que salían de la ciudad hasta que regresaban a ella una vez finalizadas las Cortes ${ }^{66}$. Este salario se mantuvo hasta 1625 en que subió a 3 ducados diarios, es decir, 33 reales o 1022 mrs., aunque se habian solicitado 6 ducados, pero la ciudad se opuso a tal aumento de sueldo.

Pero los procuradores en Cortes, además de su salario, recibían ayudas de costas y mercedes. Las primeras las repartía el Rey a su voluntad, oscilando entre 30.000 y $40.000 \mathrm{mrs}$, hasta un máximo de 100.000 mrs; las segundas consistían en la concesión de la peticiones que previamente habían solicitado al Rey los propios procuradores. En este caso se podían recibir compensaciones económicas, pero también un hábito de caballero, un oficio, etc.

A parte de estos beneficios, la procuraduría en Cortes proporcionaba un gran prestigio social, favorecía el contacto con la Corte y su burocracia, además de disponer de otros privilegios. En definitiva, las personas elegidas como procuradores rompian el limitado espacio del poder local para entrar en conexión con el mundo de la Corte.

\section{b) Los diputados del Reino}

En el año 1525, después de la derrota de los comuneros y cuando las Cortes habían quedado sometidas a la voluntad del Rey, nació la Diputación de las Cortes. Aunque la misión de los diputados del Reino en un principio fue amplia e imprecisa, pues se encargaban de velar por el cumplimiento y ejecución de lo proveído en las Cortes y atender los negocios que por las ciudades les fueran encomendados, a partir de la aprobación del encabezamiento general de las tercias y alcabalas, la administración de estos dineros pasó a ser la principal misión de los diputados.

Los diputados debían de residir en la Corte ${ }^{67}$. La duración del cargo sería de un año y su salario de $100.000 \mathrm{mrs}$. Siempre actuarian por delegación de las Cortes y estando éstas reunidas serían

66 Ibidem, Libro de Actas n. 1006, sesión del 24-1-1578

6. Ibidem, Libro de Actas $n$. 1006, sesión del 11-7-1579, en esta sesión se dio poder a Diego de Porres para que residiera en la Corte como diputado del Reino. 
los procuradores en Cortes quienes se encargarían de la gestión del encabezamiento.

Inicialmente los diputados eran dos, aunque a partir de 1544 se nombraron tres y ya no se modificó este número. Todos comenzaban y terminaban su ejercicio a la vez, por lo que no quedaba ninguno que se encargase de asesorar a los entrantes. Más adelante, el tiempo de permanencia en el cargo se amplió a tres años, pero como los periodos entre Cortes nunca eran exactamente de tres años, en 1563 se acordó que los diputados fueran nombrados de Cortes a Cortes.

La elección de los diputados se hacía por sorteo. Primeramente se sorteaba entre los procuradores en Cortes de las ciudades y villas con voto en Cortes para saber cual de ellas se encargaría de elegir entre sus regidores al diputado correspondiente. En cada ocasión se encargaban del nombramiento dos ciudades, una de las situadas al norte del Sistema Central y otra de las del sur de dicha cordillera.

A partir del año 1579 se hizo una regulación general acerca de los requisitos necesarios para ser diputado y de las incompatibilidades del cargo. Se tomó como costumbre que de entre los procuradores en Cortes salientes, se eligiera a quien debía de ser diputado, y por tanto, la calidad del elegido sería la misma que la de los procuradores. $Y$ con respecto a las incompatibilidades, excepto ser procurador en Cortes y criado del Rey, todos los demás oficios eran incompatibles.

Igual que a los procuradores en Cortes, al diputado elegido se le extendía un poder, que a la vez le servía de acreditación, y con él se presentaba ante el Consejo Real donde juraba el cargo. Cumplido este requisito, las Cortes le encomendaban una "Instrucción» que tenía que cumplir fielmente y cuando terminaba su ejercicio, estaba obligado a presentar cuentas ante las Cortes.

El sueldo de los diputados sufrió pocas variaciones. En 1570 se les abonaban 250.000 mrs., cantidad que se vio aumentada en 1588 hasta los $300.000 \mathrm{mrs}$. Se les concedian tres meses de licencia anual para que pudieran abandonar la Corte. También gozaban de ayudas de costas destinadas a sufragar los gastos de su estancia en la Corte y diferentes gratificaciones ${ }^{68}$.

68 Tomas y Valiente, F., Gobierno e instituciones en la España del Antiguo Régimen. Alianza, Madrid. 1982, p. 126. 


\section{PROCESO DE PATRIMONIALIZACIÓN. LA TRANSMISIÓN DE LOS OFICIOS}

\section{a) Proceso de patrimonialización}

El tránsito del sistema del Concejo abierto al Regimiento y el hecho de que fuera el rey quien nombrase a los regidores con carácter vitalicio, propició que estos oficios fueran codiciados por la baja nobleza urbana y que poco a poco intentaran perpetuarse en el desempeño de los mismos.

El Rey, desde el principio, concedió estos oficios de un modo libre y gratuito, como una merced real. Pero el nombramiento real enseguida comenzó a verse mediatizado por los intereses privados de los regidores, que, desde el reinado de Juan II, comenzaron a practicar el sistema de renuncias con el fin de perpetuar a los miembros de su familia en el ejercicio del cargo ${ }^{69}$. Dichas renuncias constituían el mecanismo mediante el cual el regidor saliente renunciaba a su oficio en manos del Rey a la vez que recomendaba a su sustituto en el oficio, merced que el Rey solía conceder en todas las ocasiones, aunque no estuviera obligado a ello jurídicamente.

En Castilla nunca estuvo regulado jurídicamente el sistema de transmisión de los oficios públicos. Siempre estuvo prohibida la venta de los mismos, aunque se adoptara en la práctica el sistema de renuncias para hacer realidad la transmisión entre particulares. La Corona comenzó dando estos oficios por merced y con el tiempo terminó vendiéndolos al mejor postor, pero, al ser la venta ilegal, tenía que realizarse ésta de un modo ficticio, encubriendo el precio de la misma bajo la forma de un donativo a la Corona por parte del adquiriente.

Las posibilidades que ofrecía la renuncia no garantizaban de forma plena la transmisión del oficio, pues el Rey podía no aceptar al recomendado. A ello se sumaba la posibilidad de incurrir en algún defзcto de forma en la tramitación del título y correr el riesgo de que éste quedase vacante.

Durante el reinado de Enrique IV se concedieron por primera vez oficios que, aunque gratuitos, fueron otorgados a perpetuidad con el fin

69 Novisima ReCopilación, Libro VII, título VIil, ley III. 
de hacerse con clientelas y fidelidades. Esta perdida de regalía por parte del monarca no lo consintieron de ningún modo los Reyes Católicos, que elaboraron la legislación suficiente en contra de la privatización de los oficios públicos en las Cortes de Toledo de 1480. Estas leyes nunca fueron derogadas, por lo que la venta de oficios públicos siempre fue ilegal en Castilla.

Las ventas de oficios públicos entre particulares comenzaron a producirse a partir del siglo XVI de forma habitual y mucho antes de que lo hiciese la Corona. La opinión de juristas y teólogos como Domingo de Soto, negaron la licitud de la venta de oficios de jurisdicción, pero admitieron las de los demás oficios, y —como dice Tomás y Valiente- «esto fue lo que terminó prevaleciendo" ${ }^{70}$. En primer lugar, la Corona empezó a vender oficios que se encontraban vacantes, pero una vez terminados estos y cubiertas todas las plazas, comenzó la política de acrecentamientos de oficios por encima de los establecidos para cada municipio.

El acrecentamiento de oficios significaba unos ingresos rápidos para la Corona. Pero al tratarse de oficios colegiados, los beneficios de los regidores iban en relación inversa al aumento de los mismos. Esto ocasionó airadas protestas por parte de los regidores, miembros de la baja nobleza urbana, que veían con preocupación la irrupción de gentes adineradas procedentes de la burguesía en lo que antes era un coto cerrado, y comenzaron a exigir el consumo de oficios acrecentados. La Corona supo sacar beneficios de estas peticiones de las ciudades. A partir de este momento se negociaron acuerdos en los que el monarca recibía ciertas cantidades de dinero para no acrecentar más oficios, a la vez que prometía consumir los que vacasen de entre los acrecentados. También dio la posibilidad de que las ciudades comprasen estos oficios pagando a sus propietarios el valor que habían pagado por ellos a la Corona.

Un paso más en este proceso de patrimonialización fue la concesión del derecho a poder renunciar sus oficios, en vida o en muerte, a los procuradores en Cortes. El siguiente paso fue la concesión de oficios por dos o más vidas. Esto quiere decir que el comprador del oficio adquiría desde el principio la posibilidad de poder transmitir en herencia o traspasar por precio el oficio así adquirido a la Corona.

70 Tomas y Valiente, F., op. cit., pág. 164. 
La Corona vendía oficios y los particulares negociaban operaciones clandestinas de compraventa, pero la plena disposición del oficio no había llegado todavía. Esto paso llegó cuando la Corona comenzó a vender oficios perpetuos por “juro de heredad". En Segovia sólo se produjo una venta de estas características en el siglo xvi y fue la venta del oficio de alférez mayor al Conde de Chinchón, pero en el siglo XVII será la tónica habitual marcada por la Corona. A partir de la segunda década de esta centuria, concretamente con la concesión gratuita de un oficio al Duque de Lerma en 1613, se dio comienzo a una práctica que no cesará en todo el periodo estudiado. Pero además de vender oficios perpetuos la Corona comenzó a vender perpetuaciones de oficios renunciables, con lo cual la inmensa mayoría de los regidores se fueron haciendo con la plena propiedad de sus respectivos oficios vitalicios.

La plena propiedad dio lugar al desglosamiento del oficio separando la propiedad y la titularidad. El hecho de poder adquirir el oficio cualquier persona física o jurídica incapaz de ejercerlo, permitió algo que hasta entonces había estado absolutamente prohibido, como fue poder efectuar el nombramiento de una persona que lo ejerciese a través de un contrato de arrendamiento.

La confluencia de la privatización plena con la presencia de gentes adineradas en el Ayuntamiento, sirvió para abrir los cauces de renovación de las oligarquías urbanas que se iban consumiendo por agotamiento biológico.

\section{b) La transmisión de los oficios}

A un oficio de regidor se podía acceder por merced real, bien fuera gratuita o mediante venta ficticia, o a través de la renunciación de quien hasta entonces lo hubiese desempeñado. En este caso existía una transmisión del oficio entre la última persona que lo hubiese desempañado y el regidor de nuevo ingreso.

En un principio las renuncias debian de ser gratuitas y efectuadas entre familiares, concretamente de padres a hijos. El hecho de que los procuradores en Cortes pudiesen transmitir sus oficios sin las limitaciones a que estaban sujetas las renunciaciones ordinarias, posiblemente fuera la causa de que se fuese generalizando la costumbre entre los demás regidores de renunciar sus oficios a favor de personas ajenas a la familia. Es posible que algunos regidores, obligados por 
las circunstancias, renunciaran el oficio "en confianza» a una persona cercana a la familia, hasta que el verdadero poseedor del oficio pudiese desempañarlo. Estas cesiones en confianza teóricamente debían de ser gratuitas, aunque cabe la posibilidad de que escondiesen algún tipo de contrato entre las partes. En otras ocasiones, para prevenirse ante la posibilidad de una muerte repentina, el propietario del oficio efectuaba una renuncia en confianza a favor de algún deudo para que no se perdiese el oficio, con la condición de que, en caso de que se produjese su fallecimiento, sus testamentarios vendieran el oficio al mejor postor, quedando la persona a quien se le hubiese dejado en confianza obligado a renunciarle a su vez a la persona que lo hubiese comprado. En definitiva, las personas que eran objeto de este tipo de renuncias en confianza eran meros transmisores del oficio, pues en la mayoría de los casos no llegaban a ejercerlos.

Para que una renuncia fuese válida el renunciante debía vivir los 20 días siguientes a la fecha de la renuncia que la ley exigia; a su vez, el nuevo regidor estaba obligado a expedir el titulo a su nombre dentro de un plazo de 30 días a contar también desde la fecha de la renuncia; y una vez puesto el título a su nombre, había que presentar en el Ayuntamiento antes de transcurridos 60 días. Este plazo se aumentó a 90 días durante el reinado de Felipe $\mid{ }^{71}$.

b.1. Contrato de Coadjutor.-Mientras los oficios fueron vitalicios el arriendo de los mismos siempre estuvo prohibido. En la segunda mitad del siglo XVI era de dominio público que las renuncias que se hacian en personas ajenas a la familia, en realidad escondían ventas y contratos entre las partes ${ }^{72}$. Sabemos que por esta época los regidores se oponían tajantemente a los contratos de arrendamiento ${ }^{73}$, con el fin de asegurar la calidad de las personas que accedieran a dichos cargos. Posiblemente por esta razón, doña Isabel de Torres, viuda don Antonio de Tordesillas, para no arriesgarse a perder el oficio de su hijo Rodrigo, menor de edad, fue por lo que solicitó permiso al Rey para que se pudiese efectuar nombramiento de Coadjutor que ejerciese el oficio en nombre de su hijo ${ }^{74}$. Este contrato de Coadjutor es muy similar a los contratos de arrendamiento que se realizaron en el siglo XVII

Novisima Recopilación, Libro VII, título VIII, leyes IV, V, VI, y VII.

CAstillo de Bobadilla, Jerónimo de, op. cit., Libro III, cap. VIII, puntos 285, 286 y 287. A.M.S., Libro de Actas n. ${ }^{\circ}$ 1019, sesión del 15-3-1605.

Archivo Histórico Provincial de Segovia (A.H.P.S.), Protocolo n. ${ }^{\circ} 153$, fol. 477. 
cuando la privatización de los oficios permitió esta práctica. Posiblemente el primero sirviera de modelo a los segundos. La principal diferencia es que no se imponía ningún precio entre las partes. En este tipo de contrato se ponian de acuerdo las partes actuantes para repartirse los beneficios anexos al oficio, incluyendo las posibles mercedes otorgadas por S. M. en caso de que el Coadjutor resultara elegido procurador en Cortes.

b.2. Arrendamiento de oficios renunciables.-Como en este tipo de oficios el arrendamiento estaba totalmente prohibido, los regidores recurrian a otros medios más sutiles. Bajo la forma de una venta, se escondía un contrato de arrendamiento.

El contrato de arrendamiento que hizo Juan de Guzmán Becerra a Juan de Cuellar es muy interesante. Ante la imposibilidad legal del arriendo del oficio se simuló una venta que no era tal, sino una operación de préstamo por valor del oficio, es decir, como si el arrendador (o prestamista) prestase una cantidad de dinero al arrendatario (o tomador del préstamo) equivalente al precio del oficio, con la única diferencia que en vez de prestar dinero líquido lo que se prestaba era el título del oficio. El arrendatario quedaba obligado a pagar al arrendador los intereses de dicho préstamo (el precio del arrendamiento) y entre las partes se ponían de acuerdo para repartirse los posibles beneficios en caso de lograr la suerte de procurador en Cortes. Lo mismo que en el contrato de Coadjutor y después en los de arrendamiento ${ }^{75}$.

b.3. Ventas de oficios renunciables.-En el Archivo de Protocolos es difícil encontrar una escritura de venta de un oficio renunciable. El hecho de estar prohibida la venta de oficios públicos, induce a pensar que, no obstante, estas se producian, pero tomando una serie de precauciones.

Aun con las dificultades citadas hemos encontrado la venta del oficio de Diego del Río Machuca a Antonio Navacerrada Bonifaz. La venta se produjo en el año 1600 y una vez fijado el precio a pagar por el oficio, se pusieron de acuerdo en pagar una cantidad al contado, en concepto de fianza, y el resto se pagaría a plazos. El comprador estaba obligado a hipotecar el oficio y una serie de bienes inmuebles

75 A.H.P.S., Delegación de Hacienda, D.H., 8/36, 16-3-1605; D.H., 8/37, 17-3-1605; D.H., 8/41 y D.H. $9 / 4,16-3-1609$. 
como garantía del cobro. El vendedor tenía que renunciar el oficio a nombre del comprador y entregarle el título para que éste pudiera ponerle a su nombre. En caso de que el vendedor muriese antes de los 20 días que la ley mandaba para que la renuncia fuese válida, el comprador quedaba libre de todo compromiso y se le devolvía la fianza adelantada. Tanto el vendedor como el comprador se comprometían en que los bienes hipotecados relacionados en el contrato estuvieran libres de toda carga. Con estas condiciones la escritura quedaba terminada y ninguna de las partes podía volverse atrás, salvo en las posibles especificaciones hechas en él contrato ${ }^{76}$.

b.4. Ventas de oficios perpetuos.-La venta de oficios perpetuos no difieren gran cosa con respecto a las que hemos visto sobre los oficios renunciables. La única particularidad digna de mención residía en que al gozar los regidores de la plena propiedad de sus oficios y poderlos dejar en herencia, muchas de las ventas se producían como consecuencia de corresponder el oficio a varios herederos y como el oficio debía quedar indiviso, estos se veían obligados a llegar a acuerdos entre sí, teniendo que pagar - quien se hiciese cargo del oficio- la parte proporcional que correspondiese a los demás herederos.

Del mismo modo que la Corona había vendido oficios vitalicios, también vendió oficios perpetuos. En estos casos el comprador se obligaba a pagar el precio estipulado a los tesoreros de S. M., que generalmente era más barato que el que se observa en las operaciones entre particulares, $y$, como en las transacciones privadas, también podía pagarse a plazos ${ }^{77}$.

b.5. Arrendamientos de oficios perpetuos.-La plena propiedad de los oficios permitió la posibilidad de poderlos arrendar. Es indudable que el elevado precio de los oficios significaba el mejor método de selección, pues sólo estaban al alcance de quines dispusieran de grandes fortunas y tuvieran la posibilidad de convertirlas en dinero líquido. De todos modos, al desglosarse la propiedad y la titularidad del oficio, en los casos en que el propietario no estuviese habilitado para ejercerlo, no le quedaba más remedio que nombrar a una persona idónea

\footnotetext{
A.H.P.S., Protocolo n. ${ }^{\circ} 752$, íols. 528 y ss.
}

Ibidem, Protocolo n. 1390 , fols. 334 y ss. 
para que lo ejerciese en su lugar a través del consiguiente contrato de arrendamiento.

En primer lugar el poseedor del oficio tenía que solicitar permiso al Rey para poder efectuar el nombramiento en la persona que fuese a ejercerlo. Una vez concedida esta licencia, se formalizaba la escritura de arrendamiento en la que se relacionaban todas las condiciones en que se hubiesen puesto de acuerdo ambas partes.

El tiempo de duración del contrato solía oscilar entre 1 y 8 años, aunque lo normal es que fuera por un periodo de 3 ó 4 años. El arrendatario cobraba para sí todos los emolumentos y aprovechamientos que en razón del oficio le pertenecieran y gozaba de todas las preeminencias inherentes al cargo. También quedaba obligado a sacar el título del oficio y a pagar todos los gastos de expedición. Una vez tomada la posesión del oficio tenía que devolver el oficio a su verdadero propietario y cuando terminase el tiempo del contrato, tendría que renunciar el oficio a nombre de quien le dijera el arrendador. En caso de muerte del arrendatario sus herederos quedaban libres de las obligaciones fijadas en la escritura y el arrendador podia disponer del oficio a su voluntad. La cantidad que se solía pagar por el arriendo solía andar alrededor de los 150 ducados anuales ${ }^{78}$.

\section{c) Sobre el consumo de oficios}

La venta indiscriminada de oficios por parte del monarca a partir de 1543 y que, como dijimos más atrás, llegó a alcanzar el número de 38 regidores, cuando en realidad la ciudad de Segovia tenía establecido que fueran 24 , levantó airadas protestas por parte de los regidores segovianos, que veían con preocupación como se abría el hasta entonces coto cerrado de los oficios de gobierno municipal. La venta de oficios sólo estaba al alcance de aquellas personas que dispusieran de la cantidad en metálico necesaria como para soportar la inversión que suponía un oficio de regidor, y estas personas no eran precisamente los miembros de la nobleza tradicional, sino algunos acaudalados segovianos que habían amasado sus fortunas a través del ejercicio de las actividades mercantiles y manufactureras.

78 ibidem, Protocolo n. ${ }^{\circ} 1358$, fols. 708 y ss. 
La preocupación de las clases tradicionales de la ciudad era doble. Por un lado, mientras más personas hubiese ejerciendo las laboras de gobierno de la ciudad, menos oportunidades existirian de medrar y conseguir beneficios particulares. $Y$ por tanto, al ser los compradores gentes procedentes de la burguesía, se daba entrada en la alta sociedad segoviana de la época a los miembros de un grupo, que, al fin y al cabo, no dejaban de ser considerados más que unos advenedizos.

Para intentar frenar esta corriente la Corporación solicitó una cédula a S. M., previa negociación, para que no se acrecentasen más oficios de regidor a partir del día 1 de junio de 1560. En la cédula se especificaba que el consumo no afectaba los oficios antiguos sino solamente a los nuevamente acrecentados desde el año 1543 en adelante. En el año 1576 se volvieron a repetir las peticiones de la ciudad, prueba indudable de que el monarca no cumplía su palabra. Se siguieron acrecentando oficio y en todo este tiempo sólo se consumieron los oficios de fieles ejecutores.

En cierto modo era normal que el monarca actuase de esta manera. Si por un lado estaba la nobleza tradicional que quería seguir desempeñando en exclusiva los oficios municipales de gobierno, por otro, estaba la burguesía ascendente dispuesta a pagar lo que fuese necesario para poder entrar a formar parte de los grupos dominantes de la ciudad. Las necesidades hacendísticas de la Coronas hicieron todo lo demás.

Durante el siglo XVII se siguió con la misma atónica.

El consumo de oficio consistía en ofrecer la posibilidad a los ayuntamientos de poder comprar ellos mismo los oficios que iban a ser acrecentados por el Rey o abonar su importe a las personas que ya los hubiesen comprado, con el fin de que no se produjesen dichos acrecentamientos. Naturalmente esto iba en perjuicio de los ciudadanos pechero, que veían impotentes como se aumentaban los impuestos para cubrir unos gastos que, al fin y al cabo, a ellos no les afectaba en absoluto, pues a quienes perjudicaba era únicamente a los propios regidores.

Hasta tal punto aumentó la presión fiscal sobre las ciudades en el siglo XVII, que en el año 1625 el Rey ordenó que no se consumieran más oficio acrecentados, pues como los tenían que pagar los ciudadanos a través de sisas y otros impuestos municipales, esta presión fiscal 
ponía en peligro la recaudación de las rentas del monarca. A partir de este momento los oficios que se consumiesen tendrían que ser abonados por los regidores de sus propias haciendas ${ }^{79}$.

En definitiva, en lo que se refiere a los intereses de la oligarquía tradicional no consiguieron nada en absoluto. Se siguieron acrecentando oficios y siguieron entrando gentes procedentes de la burguesía en el Ayuntamiento. En cuanto a los fines del monarca siempre se realizaron, pues la burguesía, ávidos de honores, estuvieron dispuestos a pagar lo que fuese necesario por los oficios y las ciudades por consumirlos. O sea, los ingresos en la Hacienda por estos conceptos estaban asegurados.

\section{d) Precio de los oficios y perpetuaciones.}

En Segovia tenemos noticias de que produjeron 3 acrecentamientos en 1543 y un indeterminado número de ellos en 1557 y $1572{ }^{\circ 0}$. En 1543 el precio que pagó Francisco de Artiaga por un oficio de los acrecentados fue de 562.500 mrs ${ }^{81}$. Según Margarita Cuartas Rivero, hasta 1558 se vendieron en Segovia 8 oficios con una baja progresiva en los precios. En los años 1544 y 1559 se vendieron a $450.000 \mathrm{mrs}$; en el año 1557 a 525.000 mrs.; y el regimiento vendido a Cristóbal Suárez de la Concha en 1572 a $450.000 \mathrm{mrs}$. O sea que los precios de las regidurías tuvieron una tendencia a la baja con relación al precio inicial de $562.500 \mathrm{mrs}$. del primer oficio ${ }^{82}$. Según esta autora así sucedió en todas las ciudades de Castilla y León.

Todos estos oficios fueron vitalicios y renunciables. Sin embargo en 1566 se produjo la venta del primer oficio perpetuo que hubo en Segovia. Se creó el cargo de alférez mayor con voz y voto en el Ayuntamiento, cuyo precio de venta fue de 3.400 ducados, es decir, 37.400 reales $01.275 .000 \mathrm{mrs}$. También se vendieron en 1569 dos oficios de files-ejecutores con voz y voto y en 1576 el oficio de regidor depositario. El precio de salida de las fieles-ejecutorías se fijó en $825.000 \mathrm{mrs}$.

\footnotetext{
A.M.S., Leg. $354-5(k)$.

Ibidem, Libro de actas n. 1003, sesión del 28-4-1572.

Cuartas Rivero, M., "La venta de oficios públicos en Castilla-León en el siglo xvi". Hispania (XLIV/158/1984), pág. 501.

32 lbidem, pág. 503.
} 
y el de regidor depositario en $225.000 \mathrm{mrs}^{83}$. Según esta información el bajo precio del oficio de regidor depositario puede resultar engañoso, pero hay que tener en cuenta que para ejercer dicho oficio era preceptivo presentar una importante fianza.

La vida de los oficios de fieles-ejecutores fue efímera. El día 23 de enero de 1576 se acordó por la Corporación el consumo de los mismos y se fijó su precio en 2200 ducados, es decir, el mismo precio por el que se habían vendido por la Corona.

En el año 1589 se produjeron dos vetas de oficios por orden judicial La primera de ellas la llevaron a cabo los testamentarios de Juan de la Hoz y su precio fue de 1600 ducados; la segunda fue por encontrarse encarcelado y con deudas su propietario, Pedro de la Hoz, y se vendió por 1625 ducados.

Hasta el año 1600 no encontramos la primera escritura de venta entre particulares de un oficio de regidor. Se trata de la venta del oficio de Diego del Río Machuca a Antonio Navacerrada por 3400 ducados ${ }^{84}$. A partir de estos datos podemos observar como los precios de los oficios vendidos por la Corona o las tasaciones oficiales efectuadas por la justicia, eran mucho más baratos que los precios de las ventas entre particulares.

¿Qué sentido tenía una inversión de 3400 ducados, es decir, $1.275 .000 \mathrm{mrs}$. para conseguir un oficio cuyo salario era de $2000 \mathrm{mrs}$. al año? La respuesta se halla en que el regidor podía practicar toda clase de corruptelas en su propio beneficio, además de satisfacer su vanidad ocupando los primeros lugares en los actos públicos. Lo que importaban no eran los emolumentos propios del oficio sino las oportunidades que brindaba su ejercicio a quienes quisieran enriquecerse aunque fuera ilicitamente ${ }^{85}$.

En 1610 se consumió el oficio de regidor depositario pagando por él a su poseedor la cantidad de $1.000 .000 \mathrm{mrs}$. Hay que tener en cuenta que este oficio estaba destinado a desparecer con la vida de su propietario, pues con esa condición se habia otorgado ${ }^{86}$.

\footnotetext{
83 Ibidem, pág. 509.

84 A.H.P.S., Protocolo n. ${ }^{\circ} 752$, fols. 528-545.

85 Castillo de Bobadilla, Jerórimo de, op. cit., Libro IIl, cap. VIII, punto 289.

86 A.M.S., Libro de Actas n. 1021 , sesiones del 29-1-1610 y 7-2-1610.
} 
A partir de 1613 se hizo una merced graciosa al duque de Lerma de un oficio perpetuo y se inició, a su vez, una corriente perpetuadora por parte de la mayoría de los propietarios de oficios renunciables. El precio de estas perpetuaciones no fue siempre el mismo, pues hemos encontrado dos tarifas diferentes, una de $187.500 \mathrm{mrs} .{ }^{87}$, y otra de 225 ducados ${ }^{88}$, es decir, $84.500 \mathrm{mrs}$.

Además de perpetuarse los oficios renunciables todos los oficios que se acrecentaron a partir de la segunda década del siglo XVII fueron perpetuos por juro de heredad. Lo normal es que aumentara el precio a 4000 ducados, pero, a veces, se produjeron rebajas en función de las preeminencias que gozara o no el oficio. En la década de los Treinta se vendieron oficios con la facultad de poder nombrar teniente, entrar con armas de espada y daga y tener una antigüedad preferente en el Ayuntamiento por precio de 4000 ducados ${ }^{89}$, sin embargo, los que gozaron de estas preeminencias costaron 3400 ducados solamente ${ }^{90}$.

Lo cierto fue que el precio de los oficios acrecentados por la Corona no sufrieron variaciones importantes y en 1651 el valor de un oficio sin ningún privilegio habia subido a 4000 ducados, pero las ventas entre particulares alcanzaron límites insospechados.

Hasta mediado el siglo xvII el precio de los oficios vendidos entre particulares estuvo alrededor de los 60.000 reales ${ }^{91}$. Pasada la mitad de la centuria los precios se pusieron por las nubes. En 1664 Luis de San Millán vendió su oficio a Juan Espinosa Núñez por 77.000 reales ${ }^{92}$ y en 1670 Francisco de Azcárate compró el oficio a la viuda de Jerónimo de Aldana por 8500 ducados, es decir, 93.500 reales ${ }^{93}$.

Vistos estos ejemplos, es de suponer que no se trataba de conseguir el honor que el ejercicio del cargo proporcionaba, que era muy importante, sino que hay que suponer que para invertir tan grandes cantidades de dinero líquido, las expectativas de beneficios tenían que ser muy importantes.

\footnotetext{
${ }_{87}$ Ibidem, Libro de Actas n. ${ }^{\circ}$ 1026, sesión del 23-8-1619.

88 Ibidem, Libro de Actas n. ${ }^{\circ}$ 1033, sesión del 23-8-1631.

89 Ibidem, Libro de Actas n. ${ }^{\circ}$ 1035, sesión del 24-12-1634.

90 Ibidem, Libro de Actas n. ${ }^{\circ}$ 1038, sesión del 11-7-1638.

¿1 Ibidem, Libro de Actas n. ${ }^{\circ}$ 1039, sesión del 20-11-1645; A. H. P. S. Protocolo n. ${ }^{\circ}$ 1395 , los. 348 y ss.

92 A.H.P.S., Protocolo n. 1225 , fols. 213 y ss

92 Ibidem, Protocolo n. 1775 , fols. 735 y ss.
} 


\section{CONCLUSIONES}

Cuando se repoblaron las tierras de la Extremadura Castellana, la peligrosidad que presentaban estos territorios colocó en una posición privilegiada a los hombres encargado de su defensa. En estos primeros momentos la caballería villana estaría dotada de escasas obligaciones políticas al estar aún presente el delegado regio, pero a partir de la constitución de la Comunidad de Ciudad y Tierra, el gobierno municipal quedó encomendado a éste grupo dirigente.

Desde antiguo, los burgueses acomodados trataron de acceder a los cargos concejiles ocupados en exclusiva por los hombres de armas. Estos burgueses enriquecidos pronto estuvieron en situación de competir con los caballeros que monopolizaban el poder municipal, denunciando ante la Corte la situación de pobreza de algunos de ellos, hasta el punto que les impedía mantener caballo y armas, y, por lo tanto, no debían de gozar del honor de confiarles el gobierno de la ciudad.

La situación existente en aquellos lejanos tiempos era la siguiente: por un lado, los que tenían bienes suficientes para mantener caballo y armas y, aunque no fueran caballeros, adoptaron de estos su apariencia externa. Por otro, los herederos de los repobladores que habian heredado el status caballeresco, aunque no hubieran elegido el oficio de las armas. ¿Qué diferencia había entre ambos grupos? En definitiva, lo que importaba, sobre todo, era la apariencia de caballero. Por esta razón, en Segovia, los límites entre los estratos más elevados de la pechería con el estado caballeresco, siempre fueron muy difusos y, así, en cuanto aquellos lograron la exención, entraron a formar parte de éste. Que un caballero corriese el riesgo de ser despojado del derecho de exención como pedían los burgueses adinerados, por el mero hecho de perder sus rasgos distintivos - el caballo y armas - deja a las claras que entre los caballeros y los burgueses adinerados siempre existió una línea muy difusa y permeable en ambas direcciones.

Esta documentada la entrada de familias conversas en la oligarquía segoviana desde el siglo XVI en adelante. Quizá por eso, los regidores que lograron alguna procuraduría de Cortes, no pusieron mucho interés en lograr hábitos de caballero, conscientes de que una investigación sobre sus antepasados y sobre el origen de sus riquezas, sacaría a la luz sorpresas indeseadas.

Desde la creación del Regimiento en el año 1345, hubo presencia en el Ayuntamiento tanto de caballeros como de miembros del Común 
de los ciudadanos. Los Reyes Católicos acabaron con las diferencias existentes entre los regidores según el estamento del que procedieran. Al acabar con estas diferencias se afianzó una clase superior, la de los regidores, por encima de los caballeros de los Nobles Linajes y por encima del Común de la ciudad. Nació así un grupo oligárquico que sobre todo defendía sus propios intereses. La ciudad se aseguraba su gobernabilidad pero a costa de que el Común perdiera toda su participación en el gobierno de la misma.

La dinámica municipal y el quehacer cotidiano sobre el gobierno de la ciudad eran los cometidos de los regidores. Pero aunque en Segovia hubo generalmente 32 regidores no todos participaron en la vida municipal en la misma medida. Se ha comprobado que un $18 \%$ de regidores no asistía nunca al Ayuntamiento. Los días que más regidores asistían eran aquellos en que se celebraba el sorteo de procuradores en Cortes, o en casos muy extraordinarios, en que asistían entre 28 y 30 regidores. Los que verdaderamente participaban en la vida municipal eran entre 9 y 10 regidores, es decir, el $29 \%$ del total, que eran los que asistian más regularmente. Aunque si nos remitimos a los que lo hacian de forma cotidiana, el número baja a 6 regidores, lo que supone el $18 \%$. Este era el reducido número de regidores que gobernaban la ciudad, pero también eran los que se beneficiaban de las oportunidades de sacar un provecho económico del oficio.

La obligatoriedad de asistir al menos a 33 ayuntamientos al año, solamente la cumplían entre 14 y 15 regidores, es decir, el $45 \%$. Qué más de la mitad de los regidores prescindieran del sueldo anual del oficio, es una prueba de que no eran las ventajas económicas que reportaba el cargo como tal lo que atraía a estos individuos (a no ser que fueran los que cargaban con el peso de la política diaria), sino el honor que proporcionaba el desempeño del mismo y por ser el primer paso de una carrera política que podía culminar en el desempeño de un oficio cortesano.

Generalmente el oficio de regidor definía socialmente a estos individuos y en muchos casos borraba sus antecedentes. Aunque este cargo estaba reservado a la clase de los caballeros, en Segovia siempre fue muy permeable a los miembros de la burguesía mercantil y manufacturera adinerada. Los Nobles Linajes desplazados de la vida municipal como institución, pasaron a ser el trampolín utilizado por los advenedizos para instalarse en la aristocracia urbana. La enseñanza universitaria fue otra vía de acceso. Pero en definitiva, lo que distinguía 
a todos ellos era la riqueza y la apariencia de llevar una vida de estilo caballeresco.

El hecho de que fuera el Rey quien nombrase a los regidores y permitiera la renuncia como modo de transmisión de los oficios, propició que la baja nobleza urbana se fuera perpetuando en el desempeño de los mismos. La creación del Regimiento dio inicio a un proceso de centralización política que culminó en le siglo XVIII, pero España no llegó a ser un estado burocrático centralizado moderno. Al contrario, en el siglo XVI, cuando los reyes se desentendieron de la recaudación de impuestos, rentas y jurisdicciones, dejándolas por conveniencia administrativa en manos privadas de potentados locales, se produjo un resurgimiento señorial de tipo casi feudal. A la Corona le interesó tener sometidas a las ciudades cuando el crecimiento urbano fue mayor $y$, sin embargo, dejó a los grades nobles en paz en sus posesiones rurales donde actuaron casi como señores independientes.

El proceso de patrimonialización sufrido por los oficios de regidor tiene mucho que ver con la pérdida de autonomía concejil. La Guerra de las Comunidades fue un intento de recuperar antiguas tradiciones de libertad y autonomía, pero el fracaso del movimiento dejó a las oligarquías urbanas en manos del monarca. La política de acrecentamientos seguida por parte de la Corona, al tratarse de oficios colegiados, provocó las quejas de los que hasta entonces habian desempeñado estos oficios en exclusiva. Los beneficios que de forma indirecta lograban los regidores a través del ejercicio de gobierno, iban en relación inversa al aumento del número de regidores. La entrada de gentes adineradas en el Ayuntamiento, dio lugar a que entre los regidores se iniciara un proceso de cerramiento de clase, para seguir con el monopolio del gobierno local en exclusiva. Cuantas más posibilidades hubiese de perpetuar el oficio en la familia, más se reduciría la entrada de nuevos miembros.

Es indudable que la venta de oficios acrecentados y la privatización plena de los mismos, sirvió de cauce de renovación a las oligarquías urbanas que se iban consumiendo por agotamiento biológico. Pero en Segovia este proceso no supuso un cambio brusco y traumático, pues los burgueses que accedieron al oficio de regidor, no buscaban el triunfo de su clase ni sustituir a la caballería tradicional, sino la integración en ese grupo social adoptando los modos de vida y los códigos de conducta de aquellos a quienes venían a sustituir. 
La renovación de la oligarquía existió, pero en Segovia quedó difuminada por los matrimonios que se produjeron entre los miembros de la caballería tradicional y los miembros de la burguesía. Como vimos más atrás, la permeabilidad entre los nuevos ricos y la caballería tradicional fue posible $y, \sin$ apercibirse claramente, facilitó el reconocimiento social de los recién llegados. También supuso un cauce de renovación de la clase dirigente. Los cruces matrimoniales facilitaron el ascenso de la burguesía y difuminaron su presencia.

En el año 1506, de los 24 regidores que había en Segovia, 16 de ellos procedian del estamento caballeresco y los 8 restantes del Común de la ciudad, es decir, el $66,6 \%$ y el $33,3 \%$ respectivamente. En 1561 de 32 regidores, 14 de ellos vivían en parroquias situadas en el barrio de los caballeros, es decir, el $43 \%$ y 15 regidores vivían en parroquias asentadas en las vías comerciales de la ciudad, es decir, el $47 \%$. No es un dato determinante, pero resulta significativo que más de la mitad de los regidores vivieran en parroquias típicamente burguesas. Siguiendo con este criterio, en 1586 el $28 \%$ de los 32 regidores vivían donde los caballeros, el $59 \%$ en las parroquias burguesas y el $13 \%$ fuera de la ciudad. Y, por último, en el censo de 1611, se observa la presencia del $23 \%$ en el barrio de los caballeros y el $76 \%$ en las parroquias burguesas. Esto nos puede dar una idea de la evolución sufrida por los miembros de la oligarquía segoviana.

En conclusión, podemos decir que aunque considerados y tenidos por caballeros, si nos atenemos a sus orígenes o a las ocupaciones privadas de los regidores, vemos como se invirtieron los términos. Y si al principio del siglo XVI un 33,3\% procedía de la burguesía y el $66,6 \%$ restante del estamento caballeresco, a principios del xvII se habia dado un vuelco a la situación y se contaban un $76,8 \%$ y un $23,2 \%$ respectivamente. 